NBER WORKING PAPER SERIES

\title{
PRIVATE EQUITY AND FINANCIAL STABILITY: \\ EVIDENCE FROM FAILED BANK RESOLUTION IN THE CRISIS
}

\author{
Emily Johnston-Ross \\ Song Ma \\ Manju Puri \\ Working Paper 28751 \\ http://www.nber.org/papers/w28751 \\ NATIONAL BUREAU OF ECONOMIC RESEARCH \\ 1050 Massachusetts Avenue \\ Cambridge, MA 02138 \\ May 2021
}

This version: April 2021. First Version: September 2019. For helpful comments, we thank Haelim Anderson, Christa H.S. Bouwman, Michael Ewens, Edith Hotchkiss, Filippo Mezzanotti, David Robinson, Paul Soto, James Weston, and Ayako Yasuda. We also thank seminar and conference participants at AFA Annual Meeting, Corporate Finance Conference at Washington University in St. Louis, Econometric Society World Congress, MFA Annual Meeting, Southern California PE Conference, Texas A\&M University Young Scholar Symposium, Bank of Italy, Boston College (Carroll), CAFRAL (Reserve Bank of India), Duke University, European Stability Mechanism, FDIC Center for Financial Research, Florida (Warrington), Georgia Tech (Scheller), Luxembourg School of Finance, Michigan State, New York Fed, Northwestern (Kellogg), UBC (Sauder), UMass-Amherst (Isenberg), Utah (Eccles), Villanova, Virginia (Darden). Xugan Chen, Gen Li, and Yi Wang provided excellent research assistance. We are grateful to subject matter experts at the FDIC, including Joshua Christie, Lynn Shibut, Jane Slattery, and many others, for sharing their knowledge of institutional details. Any errors are entirely our own. The analysis, conclusions, and opinions set forth here are those of the author(s) alone and do not necessarily reflect the views of the Federal Deposit Insurance Corporation. The views expressed herein are those of the authors and do not necessarily reflect the views of the National Bureau of Economic Research.

NBER working papers are circulated for discussion and comment purposes. They have not been peer-reviewed or been subject to the review by the NBER Board of Directors that accompanies official NBER publications.

(C) 2021 by Emily Johnston-Ross, Song Ma, and Manju Puri. All rights reserved. Short sections of text, not to exceed two paragraphs, may be quoted without explicit permission provided that full credit, including $\odot$ notice, is given to the source. 
Private Equity and Financial Stability: Evidence from Failed Bank Resolution in the Crisis Emily Johnston-Ross, Song Ma, and Manju Puri

NBER Working Paper No. 28751

May 2021

JEL No. E65,G18,G21

\section{ABSTRACT}

This paper investigates the role of private equity (PE) in failed bank resolutions after the 2008 financial crisis, using proprietary FDIC failed bank acquisition data. PE investors made substantial investments in underperforming and riskier failed banks, particularly in geographies where local banks were also distressed, filling the gap created by a weak, undercapitalized banking sector. Using a quasi-random empirical design based on detailed bidding information, we show PE-acquired banks performed better ex post, with positive real effects for the local economy. Overall, PE investors had a positive role in stabilizing the financial system through their involvement in failed bank resolution.

Emily Johnston-Ross

FDIC

550 17th St NW

Washington, DC 20429

emjohnston@FDIC.gov

Song Ma

Yale School of Management

165 Whitney Avenue

New Haven, CT 06511

and NBER

song.ma@yale.edu

\author{
Manju Puri \\ Fuqua School of Business \\ Duke University \\ 100 Fuqua Drive \\ Durham, NC 27708-0120 \\ and NBER \\ mpuri@duke.edu
}




\section{Introduction}

Private equity (PE) has become an important component in the financial system. An extensive literature explores the effects of private equity buyouts on firm-level outcomes, such as employment, productivity, product quality, and innovation, with some papers arguing that such buyouts positively affect the operations of target companies. ${ }^{1}$ At the same time, the private equity industry generates much controversy. Critics of the private equity industry often argue that private equity transactions involve heavy financial engineering schemes that introduce a substantial debt burden on the target companies and default risks to the banking sector (Andrade and Kaplan, 1998; Kaplan and Strömberg, 2009). This concern could be exacerbated during an economic downturn due to the cyclicality of private equity investment (Bernstein, Lerner, and Mezzanotti, 2019).

How does private equity interact with and affect the stability of the financial system, especially during periods of crisis? Despite its importance, there has been little research on the matter. In this paper, we investigate this question by examining private equity investors' engagement in the failed bank resolution process in the aftermath of the 2008 crisis. This is a novel setting to study private equity and financial stability. To begin with, bank failures and their resolutions are a salient feature of financial crises, and have a significant real effect on the economy (Bernanke, 1983; Granja, Matvos, and Seru, 2017). Indeed, banks are central to the functioning of financial markets and have important externalities (Gorton and Winton, 2003). As a result, our setting allows us to examine private equity investors' role in one of the most crucial steps in stabilizing the financial system in a crisis. Moreover, the setting is unique compared to most of the PE literature, and thus demands a separate investigation. Compared to industrial firms in which private equity investors often intervene, banks are subject to more stringent regulation, ${ }^{2}$ and require unique expertise and human capital. This non-bank involvement in banks also generates a lot of controversy.

The role of PE in failed bank resolution is a priori unclear. There are concerns that PE investors could exert negative influences on financial stability. PE investors may take advantage of the fragile banking sector and target high-quality assets under fire sales. Banks have safety nets

${ }^{1}$ See, for example, Kaplan (1989), Lichtenberg and Siegel (1990), John, Lang, and Netter (1992), Boucly, Srear, and Thesmar (2011), Lerner, Sorensen, and Stromberg (2011), Davis et al. (2014), Bernstein et al. (2016), and Bernstein and Sheen (2016).

${ }^{2}$ For example, a list of federal banking regulations can be found here: https://www.stlouisfed.org/federalbanking-regulations/. 
and backstops that may also be exploited by PE investors. Further, PE acquisitions may be value destroying if PE investors are not well prepared to operate a bank.

On the other hand, PE investors could have a unique advantage in stabilizing the financial system through acquiring failed banks. First, PE investors have a higher risk appetite, and this may allow them to target riskier and lower quality failed banks that are less appealing to traditional bank acquirers. Under this line of reasoning, PE investors complement the bank acquirers through the "selection" of failed banks. Second, during those financial downturns, PE investors may have relatively more stable funding (Bernstein, Lerner, and Mezzanotti, 2019), bringing in new capital in times of capital scarcity. Third, PE investors have the expertise to turn around distressed firms in adverse economic situations (Hotchkiss, Smith, and Strömberg, 2011; Jiang, Li, Wang, 2012; Cohn, Hotchkiss, Towery, 2020).

This paper exploits detailed, proprietary failed bank acquisition data at the FDIC. We observe information on failed banks, bidding, and acquisition activities. We identify PE investors who participated in failed bank resolutions, both as bidders of the failed bank's assets in failed bank auctions and as acquirers of the failed bank's assets when awarded the winning bid. We further augment the data with bank operation data extracted from the Consolidated Reports of Condition and Income "Call Reports," the FDIC Summary of Deposits (SOD) and the FDIC Reports of Structure Change. We also supplement our data using PE-level information from Preqin.

Who do PE investors acquire? PE acquisitions are significant, totaling about a quarter of all failed bank assets acquired in the period 2009-2014. We find that PE investors bid for, and eventually acquire, failed banks that are of poorer quality and higher risk compared to those that were acquired by banks. PE-acquired banks, on average, are larger and more undercapitalized, evidenced in their lower tier 1 risk-based capital ratio (measuring a bank's core equity capital). They tend to have a lower ratio of core deposits (which measures a stable source of funds for the bank). PE-acquired failed banks also have lower profitability prior to failure, captured by the net interest margin. PE-acquired banks also hold larger proportions of riskier loans. For example, during the crisis, construction and development (C\&D) loans had higher levels of underperformance leading to an increase in credit risk ratings. PE-acquired banks, on average, hold 27 percent more $C \& D$ loans, relative to the 17.9 percent $C \& D$ loans to total loans in bank-acquired institutions. 
PE investors also focus on banks that are less likely to immediately synergize with healthier existing banks. Granja, Matvos, and Seru (2017) show that bank acquirers are more interested in purchasing failed banks that are geographically close to themselves to realize informational benefits and economies of scale. Hence the natural acquirers of failed banks are healthy local banks. We show that failed banks whose neighboring banks are in worse health are more likely to be acquired by PE investors - when neighboring banks have lower tier 1 capital, higher proportions of C\&D loans and higher proportions of other real estate owned (OREO), which can reflect larger amounts of distressed real estate properties held by the bank due to foreclosure.

This evidence together points to a sorting pattern of failed banks with their plausible acquirers: $\mathrm{PE}$ acquirers complement banks in this market by bidding and ultimately acquiring lower-quality and higher-risk failed banks. In doing so, PE investors help channel capital that can fill the gap created by a weak, undercapitalized banking sector and help meet the huge needs for new capital. The PE presence allows more failed banks to avoid being liquidated and the local financial system to be preserved. Comparing our data with a simple counterfactual world without PE investors acquiring any banks, 25 (5.5 percent) more of the banks that failed during this time would have been liquidated, and another 37 (8.1 percent) would have gone to a higher-cost bidder. In total, we estimate that PE acquisitions allowed the FDIC to reduce resolution costs by $\$ 3.63$ billion.

We next ask: how do PE-acquired banks perform post acquisition? Filling the gap in the failed bank resolution process left by undercapitalized bank buyers, as documented above, is valuable. However, if PE interventions introduce excessive risks and long-term underperformance into the financial system, the overall impact of PE would have to be viewed with caution. The empirical challenge to isolate the effect of PE on post-acquisition performance of banks is the very acquisition selection pattern that we present above. Banks and PE investors target a different segment of the failed bank market, making any post-acquisition pattern a combination of treatment and selection.

To better identify the effect of PE acquirers, an ideal experiment would compare the postacquisition performance of two otherwise similar banks of which one is quasi-randomly allocated to a PE investor and one to a bank. Our empirical strategy leverages the proprietary FDIC failed bank bidding data to generate a quasi-random sample. We proxy the ideal experiment by focusing on a set of banks that were bid on by both PE investors and by banks (i.e., selectable to both PE 
investors and banks) and whose bidding values were close (below five percent of the total bank assets). Essentially, the exercise compares banks that were (marginally) won by bank acquirers and those (marginally) won by PE investors. This comparison allows us to significantly mitigate the confounding selection problem and more cleanly isolate the direct effect of PE intervention. Reassuringly, in this quasi-random sample, PE-acquired banks and bank-acquired banks look statistically identical along dozens of characteristics, and the winning probability of PE investors and banks in those auctions are nearly identical (52 percent vs. 48 percent).

Armed with this empirical strategy, we explore several different performance metrics. First, we track branch closures of acquired failed banks. PE-acquired failed bank branches are less likely to close than bank-acquired failed bank branches. This result is robust to our preferred specification in which we compare two bank branches that belong to two banks that failed in the same year and the same state. For these branches, the only difference is whether it was quasi-randomly won by another bank or a PE investor. It is important to note that the lower branch closing rate of PEacquired banks is not due to the fact that bank mergers often lead to consolidation of local branches, which would make the higher closing rate in bank acquisitions mechanical. In fact, we also find a higher probability of exiting a county altogether in bank-acquired banks, which cannot be explained merely by consolidating local branches. Next, we find that PE-acquired banks experience a significantly higher increase, roughly 35 percent higher growth across different specifications, in branch-level deposits compared to other failed banks. Given deposits are the base for profits, lending capacity, and market power, we interpret this as a positive indicator for PEacquired banks.

The ability to maintain the scale of operation and a robust deposit base is an important indicator of bank health and performance. More importantly, providing stable access to credit by operating a local branch has important consequences for local businesses and the recovery from the financial crisis (Nguyen, 2019). The positive performance patterns of PE-acquired failed banks lead us to hypothesize that those acquisitions facilitate the regional economic recovery from the crisis, and this is the basis of our next test.

We adapt the same quasi-random framework to a county-level analysis. In this analysis, we compare two counties - each county has a failed bank branch, but one is acquired by a PE investor and one is acquired by a bank. These counties are statistically identical prior to the acquisitions. 
During the post-acquisition period, however, those counties with PE acquisitions experience stronger recovery from the crisis-faster employment growth and increased total and per capita income. One potential channel for this is the sustained lending activities supported by the acquired bank branches. Compared to bank-intervened counties, PE-intervened counties witness higher growth in small business lending, both in terms of the number and amount; those loans are also made at a lower interest rate.

The documented positive performance may be partially attributable to the expertise of the management team that PE investors bring into failed banks. Using hand-collected data on CEOs appointed at banks after PE acquisitions, we show that PE investors hire ex-bankers who, on average, have nearly 30 years of experience in the banking industry, and more than half of them were CEOs of other banks before being appointed at the failed banks. More than 60 percent of the CEOs had experience in the local area of the failed bank, more than a third specialized in turnaround management and troubled and distressed assets, and about a third had previously founded a bank that eventually merged with a larger buyer.

Taken together, our results suggest that private equity plays an important role in failed bank resolution in a time of crisis. PE investors provide much needed capital in acquisitions, which helps fill the gap of a weak banking sector at a time when the natural potential acquirers-local banks - are themselves in distress. PE acquirers also help turn around the acquired failed banks, preserving their branch structure, helping deposit growth, and managing the loan portfolio losses, with positive effects for the real economy. While there are natural policy concerns in allowing PE firms to form bank holding companies and in bringing in non-banks into banking in general, our results suggest that, despite these concerns, private financial investors can play a positive role in resolving distressed banks in a crisis.

This paper connects to several strands of literature. It is related to an extensive literature that studies the role of private equity in the economy (e.g., Kaplan, 1989; Lichtenberg and Siegel, 1990; John Lang and Netter, 1992; Boucly, Sraer, and Thesmar, 2011; Lerner et al., 2011; Cohn, Hotchkiss and Towery, 2013; Davis et al., 2014; Bernstein et al., 2016; Bernstein and Sheen, 2016; DeYoung et al., 2018), and particularly in some regulated industries in recent work (e.g., Eaton, Howell, and Yannelis, 2019; Kirti and Sarin, 2020; Gandhi, Song, and Upadrashta, 2021; Gupta et al., 2021). These studies mostly focus on firms and almost exclusively on normal times, while 
our focus is on the distressed state of the world. The paper on PE that is closest to ours is Bernstein, Lerner, and Mezzanotti (2019), which studies PE investment in industrial firms in the crisis and shows that PE investors did not exacerbate the negative shock to firms. However, the behavior of PE investors in a highly regulated and sensitive industry such as banking is likely different from PE's behavior elsewhere. Our key contribution is to tackle the role of PE on financial stability by directly examining the interaction between PE and the central actors-banks, particularly failed banks that can result in significant costs to the financial system.

This paper also relates to an emerging body of work examining the behavior of financial institutions during the financial crisis (e.g., Ivashina and Scharfstein, 2010; Ben-David, Franzoni, and Moussawi, 2012; Berger and Bouwman, 2013) and the resolutions of failed banks and their impacts (James and Wier, 1987; James, 1991; Vij, 2020). The closest bank failure paper to our work is Granja, Matvos, and Seru (2017), which provides a key economic insight that poor capitalization of local banks, who are the natural buyers of failed banks, results in substantial costs to the FDIC's resolution efforts for failed banks. Our paper contributes to this new area of research by introducing PE investors as financial buyers into the picture, a source that surprisingly buys 24 percent of the failed bank assets acquired in the resolution process during this period. We show that PE investors operate as a complementary source of funding in the resolution of bank failures at a time when the local bank buyers are themselves undercapitalized. Further, PE acquisitions do well and also benefit the real economy. From a policy perspective, our findings are supportive of the policy innovation of the OCC and the FDIC that allowed financial buyers to participate in the resolution of failed banks.

\section{Institutional Background}

In this section, we introduce background knowledge of how the FDIC resolves bank failures and, more importantly, how PE investors can become a qualified player in this process. Roughly five hundred banks failed during the financial crisis, putting a large strain on the financial system. This fact can be seen clearly in Figure 1, which plots the number of bank failures (Panel A) and the total assets at failure (Panel B) from 2000 onward.

When a bank fails, the FDIC is appointed receiver by the failing institution's chartering authority. To address bank failures, the FDIC used the Purchase and Assumption (P\&A) resolution 
method in roughly 95 percent of the cases during 2009-2014, and these are the transactions studied in this paper. ${ }^{3}$ In a P\&A transaction, the FDIC uses a process that resembles a first-price sealed bid auction to sell some or all the assets and liabilities of the depository institution. Granja, Matvos, and Seru (2017) provide a detailed description of how the process of failed bank resolution works; we review relevant points here and refer interested readers to their paper and to the FDIC's Resolutions Handbook ${ }^{4}$ for further details.

\section{[Insert Figure 1 Here.]}

To sell a failed bank, the FDIC first generates a broad list of potential bidders that have expressed interest in bidding for failed institutions and that satisfy a list of requirements, such as satisfactory capital and supervisory ratings. Upon signing a confidentiality agreement, interested parties may be granted access to a virtual data room for the review of available information, which can include loan reviews, schedules representing the value of items on the failed bank's balance sheet, and operational information. Interested parties can place sealed bids for the failed bank based upon standard transaction terms, resembling a first-price sealed bid auction. Using its proprietary least cost test, ${ }^{5}$ the FDIC selects the bid whose terms entail the least-estimated cost for the Deposit Insurance Fund (DIF) if those costs are below the reservation value set by the FDIC, which is unknown to bidders. The bank is then closed, and the FDIC transfers assets and deposits to the acquirer. $^{6}$

In the past, private investors have generally been excluded from bidding on failed institutions because they themselves were not chartered banks. However, in 2008 the Office of the Comptroller of the Currency (OCC) began making it easier for PE investors to participate in failed bank auctions by creating a "shelf charter" program. A shelf charter allows investors to bid on failed banks despite not being affiliated with an existing bank. The OCC also made available an

\footnotetext{
${ }^{3}$ The remaining failures were resolved by the FDIC through depositor payouts and asset liquidation.

${ }^{4}$ Federal Deposit Insurance Corporation (FDIC). 2019. Resolutions Handbook, Revised January 15, 2019. https://www.fdic.gov/bank/historical/reshandbook/resolutions-handbook.pdf.

${ }^{5}$ The least cost test evaluates the liquidation cost of the failed institution against the cost of alternative resolution options. A few details are worth noting here: The Federal Deposit Insurance Corporation Improvement Act (FDICIA) of 1991 requires that the FDIC select the bid that results in the least costly resolution to the Deposit Insurance Fund (DIF). As a statutory requirement, this process for bid selection does not vary from bank to bank. Additionally, the FDIC's valuation of liquidation, the valuation of submitted bids, and the details of the least cost test itself are all unknown to bidders.

${ }^{6}$ Since failed banks are often smaller in size, concerns like "too big to fail" or antitrust issues generally do not come under consideration by the FDIC when managing the bidding process and picking the winner.
} 
“inflatable charter," which allows PE investors to buy a small, non-failing bank with the intention of growing it quickly through subsequent failed bank acquisitions. There were twenty distinct charters, obtained by nineteen PE consortia (more on "consortia” below), used to acquire failed banks by PE in the crisis.

\section{[Insert Figure 2 Here.]}

In the charter approval process, $\mathrm{PE}$ acquisition plans are subject to a high degree of regulatory scrutiny. Potential PE investors must submit details such as the proposed bank management team qualifications, the sources and amount of capital available to the bank, and the business plan describing intended operations of the acquired bank. The information gathering, application, and approval process typically occurs well in advance of any specific acquisition opportunities that may arise. In addition, because PE firms engage in non-banking activities, they must also apply to the Federal Reserve Board for preliminary approval to form a bank holding company (BHC).

Most PE investors apply for a bank charter and form a BHC as a consortium together with a number of other PE firms, often in the form of an LLC with PE firms as shareholders. This can allow greater access to capital and help to leverage relevant expertise and connections. From a BHC regulatory perspective there are advantages as well-firms with less than a 25 percent share of voting securities or up to one third of total equity (provided that this includes less than 15 percent of voting securities) are not subject to BHC regulation by the Federal Reserve Board. Applying as a consortium can help limit the equity investments of individual PE firms below these regulatory thresholds. For example, a number of PE firms might form an LLC with equity shares of the individual PE firm participants below the threshold. The LLC is then used for the proposed BHC and serves as the actual acquiring entity. Thus, while the holding company formed by the PE firms is exposed to BHC regulation, the individual PE firms themselves are typically not.

PE acquirers did not have restrictions on what they could bid on, aside from the usual criteria applied to other bank bidders, such as available capital and financial health. However, PE acquirers did have additional requirements imposed by the FDIC for operating the bank. Notably, PE acquirers were required to maintain a tier 1 common equity to total assets ratio of at least 10 percent for at least three years after the time of acquisition. They also had to maintain continuity of ownership for at least three years after the time of acquisition, absent FDIC approval. Further, they were not permitted to engage in any credit transactions with affiliates, meaning that they could not 
use the bank as a platform to lend to their affiliated companies or investments. ${ }^{7}$ Additional PE requirements included: pledges of cross-support if investors own 80 percent or more of two or more banks; no ownership by entities in bank secrecy jurisdictions; no opaque ownership structures; no investors having 10 percent or more equity in the same bank before failure; and required disclosure about investors and ownership to the FDIC. ${ }^{8}$

\section{[Insert Figure 3]}

As shown in Figure 3, PE investors acquired about 8.5 percent of the banks in 2009 (11 out of 129). That number is larger in money terms, with PE investors acquiring 25.2 percent of the total failed bank assets that were acquired in the resolution process in that year. ${ }^{9} \mathrm{PE}$ investors remained active in acquiring failed banks through 2014, and through all those years, they acquired 13 percent of all failed banks acquired, or 24 percent in terms of assets acquired in resolution. After 2014, PE investors stopped acquiring failed banks. This might be due to two reasons. First, bank failures returned to pre-crisis levels (below 10 every year in number), leaving limited room for PE investors to pursue these investments. Second, PE funds formed during the crisis to pursue the strategy of failed bank acquisitions reached the latter part of their typical 10- to 14-year life cycle, and thus started to focus more on operations and exit. Our main analytical sample covers the period of 2009-2014. ${ }^{10}$

\section{Data and Sample Overview}

\subsection{Banking Data}

\subsubsection{Failed Bank Data}

Between 2009 and 2014, there were a total of 482 bank failures resolved by the FDIC. Private equity acquirers purchased 62 of these failed banks, while existing banks purchased 393 failed

\footnotetext{
7 This explicitly prohibits lending to affiliates in which the PE firm has invested equity, ruling out the kind of cross-selling behavior documented in Fang, Ivashina, and Lerner (2013).

${ }^{8}$ For more details, see the Final Statement of Policy on Qualifications for Failed Bank Acquisitions, Federal Register, Vol. 74, No. 169, September 2, 2009.

${ }^{9}$ We removed liquidated banks in this analysis. Also, because the FDIC often retains a sizable portion of failed bank assets not purchased by the acquirer, the total assets acquired do not necessarily match to the total assets of the failed banks (as in Figure 1).

${ }^{10}$ It is worth noting that it is uncommon for troubled banks close to failure to restructure (e.g., be acquired by a healthy bank) outside of the FDIC resolution process. We do not find that PE investors participate in acquisitions of troubled banks outside of the FDIC resolution process.
} 
banks. ${ }^{11}$ There were 25 failed banks with no least cost bid that were liquidated by the FDIC; another two provided correspondent banking services to client banks only and were temporarily run by the FDIC as bridge banks after failure. We exclude these 27 banks from our analysis following Granja et al. (2017). Details on bank failures and their resolutions come from the FDIC. These include public information conveying the timing of failure and acquisition, the location and size of the institution at failure, the amount of assets passed to the acquirer, and the terms of the failed bank transaction (transaction type, loss share coverage, and so on). We also have proprietary FDIC information on the identity of the acquirer and on all the bidders and details of their bids.

Additionally, we utilize proprietary FDIC cost estimates used in evaluating failed bank bids. This includes the FDIC's estimated liquidation cost for the failed bank and the valuation of the winning and cover bids from the internal least cost analysis. We use these estimations to identify close bids of the same failed bank, which are useful for creating a quasi-random empirical design to isolate the effect of PE intervention. These data are also useful for making back-of-the envelope calculations of the difference in cost savings had PE investors been excluded from the auction process.

Finally, we use confidential FDIC data containing details on loan performance in loss share portfolios. Loss share participants are required to submit regular reports to the FDIC on the performance of loans covered by shared loss agreements and details on any losses incurred. Because acquired banks are typically absorbed into healthy existing banks, it is difficult to track the performance of failed bank assets once they have been acquired. However, the loss share performance data allow us to observe the performance of those assets over time, even after acquisition. This provides us with a unique and important window into the management of failed bank assets by PE and bank acquirers.

\subsubsection{Bank Characteristics}

We obtain data on the operational financial characteristics of failed banks and their acquirers from the FDIC's quarterly Consolidated Reports of Condition and Income (Call Reports) and from Thrift Financial Reports for institutions regulated by the Office of Thrift Supervision (OTS) prior

\footnotetext{
${ }^{11}$ One bank was split between two acquirers but was technically a single failed bank.
} 
to 2012. These reports contain details of the income and balance sheet characteristics for all the banks in our sample.

The Summary of Deposits (SOD) database provided by the FDIC allows us to obtain bank branch location data for each commercial and savings bank and the level of deposits. The SOD database contains information on the geographical coordinates, address, and deposits of each branch of every commercial and savings bank operating in the United States. We also complement this data using the FDIC's Reports of Structure Changes. These reports provide information on branch office openings and closings. Together, we use these sources to analyze the closing of failed bank branches, and to track changes in deposits at the county level within the footprint of the failed bank.

This geographic information on bank branches also allows us to capture the characteristics of the neighboring banks of each failed institution. Granja, Matvos, and Seru (2017) show that neighboring banks' financial health is an important determinant of the failed bank resolution process. Consistent with their paper, we define local banks as banks whose branch network overlaps in at least one zip code with the branch network of the focal failed bank.

\subsection{Private Equity Data}

Our classification of PE acquisitions comes from the charter used to bid on failed banksnamely, acquisitions that were made by non-bank bidders that obtained a shelf or inflatable charter for the purpose of failed bank bidding. While most of the funds raised by those non-bank acquirers are from PE firms, they sometimes include non-PE sources such as asset management companies, institutional investors, and family offices. However, private equity firms are the key participant in this process. For example, based upon information in SEC registration statements and FDIC depository insurance applications, we estimate that PE sources account for more than 70 percent of the ownership for each consortium on average, based upon major consortia participants identified with five percent holdings or more. Additionally, the vast majority of acquisitions conducted by those private investor consortia were led by private equity firms. ${ }^{12}$ In the Online Appendix, we show alternative definitions of PE-acquired banks based on the level of PE

\footnotetext{
${ }^{12}$ A few exceptions include two small failed banks in our sample that were single acquisitions primarily acquired through family offices and a community development bank largely acquired by institutional investors. We group these failures with PE acquisitions rather than those acquired by banks because non-bank investors made the acquisitions through the same shelf charter process used by PE. All analysis results are similar if we do not include those cases.
} 
ownership (e.g., PE shares being larger than or equal to 75 percent), and our results are not affected by the definitions.

We collect additional information about those individual PE funds from several different sources. First, we hand match those PE funds with information from Preqin. Preqin collects the quarterly aggregated investments, distributions, and net asset values (NAVs) of PE funds as recorded by U.S. pension funds and obtained via routine Freedom of Information Act requests. For funds covered by the Preqin data, we collect information on the size of the fund, the vintage year, and the background of the PE firm. We also supplement this by searching additional information from PitchBook, Crunchbase, and a general internet search.

\subsection{Real Economic Effects}

To obtain local employment and startup creation information, we use data from the U.S. Census Quarterly Workforce Indicators (QWI) to compute total employment by firm age and by county. The QWI is derived from the Longitudinal Employer-Household Dynamics (LEHD)

program at the Census Bureau. It provides total employment in the private sector in each county and employment tabulated for different firm age categories. Income data at the county level comes from the Internal Revenue Service (IRS) Statistics of Income and is measured in calendar years (i.e., January to December of each year).

For local access to small business credit, we use the small business lending data obtained from the Small Business Administration (SBA). We use contract-level information on 7(a) loans, one of the largest SBA programs, delivered through various methods (Certified Lenders Program, Preferred Lenders Program, SBA Express, etc.). We focus on both the quantity and pricing of SBA loans made in each region-year.

\subsection{Summary Statistics}

Table 1 provides summary statistics from the PE side. In the upper panel, we provide statistics at the consortium level, which is the relevant unit for failed bank purchases. As described above, typically multiple PE funds join forces to form a consortium and obtain a bank charter at the consortium level. On average, each bank acquisition consortium consists of around 3.4 PE investors, counting only those having shares of five percent or more. They, on average, bid on 5.2 
failed banks, ${ }^{13}$ and "win" 3.26 of them. Their bidding strategies are quite focused, and most of these consortia purchase banks within one state. Interestingly, 58 percent of the PE consortia include at least one PE firm that has actively participated in the distressed investment space as identified in Hotchkiss, Smith, and Strömberg (2011) and Jiang, Li, Wang (2012), suggesting that these PE firms have some experience in distressed investments and turnarounds.

[Insert Table 1 Here.]

In the bottom panel, we provide summary statistics at the individual PE level, conditioning on data availability from Preqin. On average, each PE firm joins 1.13 consortia. In other words, only around $10 \mathrm{PE}$ firms joined more than one consortium. In some cases, multiple funds in the same PE firm joined the same consortium. Those PE investors are traditional independent PE investors and are not affiliated with other banks. Importantly, most of the investing funds are of recent vintages. The median fund vintage is 2007, and more than 25 percent of the PE funds are formed in or after 2009. This suggests that those funds were likely raised for the purpose of participating in failed bank resolutions, and that they had relatively adequate funding for such actions. Most of these funds are not first-time funds, so they have accumulated networks and human capital from prior activity in the PE markets.

\section{[Insert Table 2 Here.]}

Table 2 reports summary statistics of failed banks as of the last quarter prior to failure. Most failed banks in the crisis were small community banks. The median bank size was just above $\$ 200$ million, but with a very long right tail in the size distribution. Unsurprisingly for banks that failed, the tier 1 risk-based capital ratios just prior to failure were very low-far below the average for other neighboring banks that did not fail. Liquid assets were just under 17 percent of total assets on average, and core deposits comprised almost 84 percent of total deposits. These banks tended to be heavily involved in CRE lending, making up almost 39 percent of the total loans on their balance sheets. They also held a large amount of C\&D loans, comprising almost 19 percent of their total loans on average. The ratio of C\&I loans to total loans was smaller at 10 percent, and the ratio of consumer loans to total loans was just over 2 percent. Residential lending averaged 25.9 percent of total loans. In addition, both the noncurrent loans to total loans and the OREO assets to total

${ }^{13}$ These are PE bids above the liquidation value. The average is only slightly higher at 5.7 when also including PE bids below the liquidation value. 
assets at the failed banks were much higher than at other neighboring banks, indicating portfolios in distress. Two-thirds of the banks were resolved using loss sharing agreements with the FDIC.

\section{Private Equity in Failed Bank Resolution}

We first investigate which segment of the failed bank market was targeted by PE investors, and which was targeted by banks. The result of this analysis would indicate whether PE investors are complementary failed bank buyers to incumbent banks.

\subsection{PE-Acquired and Bank-Acquired Failed Banks}

We start by performing the analysis using a logit regression framework:

$$
\operatorname{Pr}(P E=1)=\Phi\left(\alpha+\beta \cdot X_{i}+\gamma \cdot \text { Control }_{i}+\theta_{t}+\varepsilon_{i}\right)
$$

The analysis uses the cross-sectional sample of all failed banks that were eventually acquired by a bank or a PE investor. The dependent variable is a dummy that takes a value of one if the failed bank was eventually acquired by PE, and zero otherwise (acquired by a bank). We control for the size of the bank using the logarithm of the total assets at failure. Year-quarter fixed effects are included to account for the time-varying economic, market, and regulatory environments that could affect the failed bank resolution process.

\section{[Insert Table 3 Here.]}

Table 3 Panel A presents the results, reporting marginal effects calculated at the sample mean. Column (1) concerns the tier 1 risk-based capital ratio. Tier 1 capital includes the most lossabsorbing forms of capital, and therefore is an important representation of bank financial strength. The marginal effect of -0.013 suggests that, for a one standard deviation decrease in the tier 1 riskbased capital ratio, there is a 3.5 percentage point increase in the probability that the bank is purchased by PE. This is a 25.8 percent increase from the base rate of 13.6 percent. Bank size positively and significantly correlates with the probability that the bank is acquired by PE, indicating that PE investors may have had an advantage over existing banks in raising larger amounts of capital for these purchases.

In column (2) we switch to another measure of the stability of banks' sources of funding, namely the core deposits to total deposits ratio. Core deposits are made in a bank's natural 
demographic market and offer advantages to banks, such as predictable costs, low sensitivity to short-term interest rate changes, and lower run risks. The core deposits to total deposits ratio is negatively associated with PE acquisition. For a one standard deviation decrease in core deposits to total deposits, the coefficient of -0.220 translates to a 23.4 percent increase from the base rate of PE acquisition.

Column (3) shows that low-profitability failed banks are more likely to be acquired by PE investors. We use the net interest margin, which measures how much a bank earns in interest compared to how much it pays out as a ratio of interest-earning assets, as an indicator of bank profitability. This helps to mitigate the potential measurement noise for failing banks in other possible profitability measures like ROA or ROE. For example, interest-earning assets should be less wildly variable than total assets used in ROA calculations in the face of large, discrete chargeoffs in nonperforming assets; it is also not uncommon for average equity to reach negative values in banks that are failing, in which case ROE is not reported. In addition, the net interest income should be less variable than the total net income used for calculating ROA and ROE, due to the provisioning behavior for loan and lease losses (which are treated as an expense to net income on the bank's income statement) at failing banks.

Columns (4) and (5) examine the loan composition of banks. Banks with riskier asset portfolios - captured by a higher proportion of $C \& D$ loans and OREO assets to total assets - were more likely to be acquired by PE investors. C\&D loans can be more sensitive to economic or market conditions than other loan types for several reasons. For example, projects may experience budget overruns or a lack of timely progress, market conditions can change drastically in the intervening time between loan approval and project completion, and lenders may have greater difficulties extracting collateral value from an incomplete construction project in default. In the crisis, C\&D loans turned out to be particularly problematic. As the FDIC describes in its history of the crisis (FDIC, 2017), "Most banks that failed or became problem banks did so because of large concentrations, relative to their capital, of poorly underwritten and administered commercial real estate loans and (especially) ADC [acquisition, development \& construction] loans” (p.179). Similarly, a higher proportion of OREO assets is often a sign of a loan portfolio in distress.

Overall, Panel A suggests that PE investors capture a set of banks that tend to be riskier in terms of asset composition, more undercapitalized, less profitable, and may require larger capital 
injections due to their size. Moreover, these banks have lower profitability as indicated by their net interest margin. Those are all likely undesirable features in the eyes of incumbent banks. In this sense, PE investors target banks that other banks may be less willing or less able to take over.

\subsection{Local Banking Market Conditions}

Next, we further strengthen the argument that PE investors acquire a segment of banks that are unlikely to be taken over and operated by other incumbent banks. In recent work studying failed bank resolution in the crisis, Granja, Matvos, and Seru (2017) show that healthier banks are more willing to bid on and pay higher amounts for failed banks that could potentially create synergies with themselves. A primary source of synergistic benefit is in the form of geographic clustering: a large literature shows that the transmission of soft information depreciates with geographic distance (Petersen and Rajan, 2002; Stein, 2002). Moreover, geographically closer banks may be better able to harvest the economies of scale to achieve operational efficiencies. The implication of this work is that failed banks without a set of healthier banks in nearby geographic regions face greater challenges in the resolution process. This is particularly true when, as shown in Table 3, Panel A, certain failed banks had worse-than-average performance and held riskier asset portfolios that other banks may not have desired.

Is PE participation particularly important for those banks without a potential bank acquirer? We explore this question in a similar setting as in Eq. (1), except that the key explanatory variables are the conditions of the local banks. We create a set of measures to capture different dimensions of local bank conditions, in which "local" are those banks whose branch network overlaps in at least one zip code with the branch network of the focal failed bank.

Table 3, Panel B presents the results. In column (1), we focus on the neighboring banks' tier 1 risk-based capital ratio, which is calculated as the mean of this ratio for all the banks local to the failed banks. We find a negative and significant coefficient, which means that when a failed bank's neighboring banks, which are often considered the most likely acquirers, are in worse financial health, the failed bank is more likely to be acquired by private equity. The economic magnitude is in fact quite large. A one standard deviation decrease in the average neighboring bank tier 1 riskbased capital ratio is associated with a 2.92 percentage point increase in PE acquisition probability, which is a 21 percent increase from the base rate. This is consistent using other bank health measures like noncurrent loans (column (2)) and OREO (column (3)). 
In column (4), we consider another factor that could affect the capability of acquisition by local banks - the size of these banks. Even if a neighboring bank remains healthy, it is unlikely for it to obtain enough capital to purchase anything that is at its size or larger than its size. In other words, banks that are considerably larger than the failed bank may be more likely to make the purchase. We show this using a variable No. of Local Banks ( $>3 x$ Size), which is the number of local banks that are at least three times the size of the failed bank in terms of total assets. The larger this number is, the more likely that the bank will be sold to another bank and less likely to a PE acquirer.

In column (5), we examine the number of failed banks in the region. If a failed bank is in a region where a lot of other banks failed at the same time, they are more likely to be acquired by PE. This could be due to other local banks being on average less healthy and less capable of making the purchase and also because it is hard for any acquirer to purchase a large number of banks if too many fail in the same region. We show that the total number of failed banks in a state is associated with a higher probability that the bank is acquired by PE. In other words, PE investors inject new capital in regions where banks on average are in deeper distress. In the Online Appendix, we show that both the failed banks' own characteristics and their neighboring banks' characteristics matter when they enter the analysis simultaneously.

Overall, this evidence provides additional support that PE investors are complementary to existing players in the banking sector in acquiring failed banks. PE investors target a segment of the failed banks in which many traditional banks are unlikely to be interested or capable of acquiring. Specifically, they acquire underperforming banks that are riskier, particularly when the failed bank is in a region where neighboring banks experience deeper distress and thus are unlikely to be able bid.

\subsection{Further Evidence on Failed Bank Acquirer Sorting and Matching}

Results so far are based on the final bidding outcomes. But is there evidence that PE investors are actively pursuing this strategy, or are PE investors just passively bidding on all banks and only winning the low-quality ones?

Table 4 presents evidence that is consistent with the PE investors actively pursuing such a strategy. We gather this evidence by examining not only the winning PE acquisitions, but also the bidding histories of each PE. To do so, we leverage proprietary data on all bidding histories in 
FDIC failed bank auctions. We create a variable, $P E$ Bid, which indicates whether there was any PE bidding on the specific failed bank, whether it achieved the winning bid or not. The indicator captures PE bids that are above the liquidation value and non-public details on those that fall below, so it reflects all bidding activity by PE acquirers. This PE Bid variable is then analyzed as the dependent variable by using the same framework as in Eq. (1).

[Insert Table 4 Here.]

All the variables that are associated with the final acquisition outcomes, as shown in Table 3, also have similar effects in explaining the bidding activities of PE investors. Clearly, both the decision to bid and the outcome of winning are equilibrium outcomes accounting for the value and costs of the failed banks to different potential buyers and to the FDIC. Nevertheless, the evidence quite clearly suggests that PE investors actively, not passively, participate in the process.

In Figure 4, we push the argument further by visualizing the sorting and matching between acquirer types and bank characteristics. The graph compares the characteristics of failed banks and their neighboring banks across banks that are targeted by different acquirers - those bid on and acquired by PE investors, those bid on by PE investors but may eventually be won by a PE entity or an incumbent bank, and those that are only bid on and eventually acquired by other incumbent banks. For each of the characteristics, we separately show the mean across the three groups.

\section{[Insert Figure 4 Here.]}

Figure 4 shows a clear pattern of sorting. Panel A shows sorting on failed bank characteristics. PE investors bid on and successfully acquire the weakest banks (left bars) whether measured by tier 1 capital ratio, core deposits, net interest margin, or real estate owned. PE investors also target some slightly stronger failed banks over which they compete with other banks, and they may win or lose in such cases (middle bars). Banks, on the other hand, on average focus on the healthier banks in the failed bank set (right bars) — and PE investors are not even bidding in this segment. Panel B shows sorting on neighboring bank characteristics. Again, both PE bids and PE acquisitions are more likely when the neighboring banks are weak (whether measured by tier 1 capital ratios, nonperforming loans, real estate owned, or the number of failed banks in the state). This again confirms that PE investors complement bank acquirers in the market. This result also suggests that even though neighboring banks are likely the best potential buyers for failed banks operation-wise, they may be hesitant to bid and/or purchase when the bank is particularly risky or 
in deeper distress. PE investors have an edge in such cases due to their higher risk appetite and more abundant funding.

\subsection{The Value of PE Participation: A World Without PE Bidding?}

Evidence so far suggests that the value of PE investors in the financial crisis first comes from their participation and their unique focus in the failed bank market which is complementary to incumbent banks. In a world without PE investors selecting those lower-quality and riskier failed banks, they would either be acquired through lower-valued bids or be liquidated by the FDIC.

How economically important is this PE participation? We perform a simple back-of-theenvelope calculation using proprietary FDIC cost estimates used for evaluating auction bids from all failed bank deals. The FDIC estimates its cost for each submitted bid in determining the least cost resolution strategy. Starting with the total gross assets at the failed bank and taking details of each submitted bid into account, it subtracts the expected losses on assets and expected expenses from the receivership, as well as any claims on the receivership. The bidder's proposed premium on deposits or discount on assets are included as well. We use these proprietary estimates in our calculation to build on the counter-factual world in which no PE acquisitions occurred.

For all PE-acquired cases, we suppose one of the following two cases happen: (1) if there is at least one non-PE bidder, the best non-PE bidder wins, where the "best" means the lowest FDICestimated cost of resolution; (2) if there is no other non-PE bidder, the bank is liquidated by the FDIC, which as receiver must pay off insured depositors and dispose of the assets. The additional cost incurred to the FDIC without PE-acquirer participation thus can be roughly estimated by calculating the gap for PE acquirers and the counter-factual world outcomes. For case (1), there are 29 failed banks for which we calculate the difference in estimated FDIC resolution costs for the winning bid compared to the runner-up. In addition, we observe 8 further cases in which the runner-up bid in a PE acquisition was also from a PE bidder. For these, we measure the gap in cost between the winning bid and the next best non-PE bid. The aggregate savings are estimated to be around $\$ 2.34$ billion. For case (2), we observe 25 failed banks that had no other non-PE bids with a cost below the liquidation cost and would have had to be liquidated by the FDIC. The total savings to the FDIC of those PE acquisitions over liquidation costs is estimated to be $\$ 1.29$ billion.

How big is the economic magnitude of the $\$ 3.63$ billion ( $\$ 2.34$ billion $+\$ 1.29$ million) estimated? The FDIC estimated that the total cost to the Deposit Insurance Fund (DIF) of bank 
failures during the crisis was about $\$ 73$ billion. ${ }^{14}$ This means that PE participation helped the FDIC reduce the cost of failed bank resolution in the crisis by nearly five percent.

One caveat here is that in this simple back-of-the-envelope calculation, we implicitly assume that bank bidding behaviors remain the same in a world without PE. Given that the failed bank bidding process is a sealed-bid auction without even disclosing the potential bidders, removing PE investors from the bidder set should, arguably, have at best a mild impact. Additionally, this assumption likely leads us to underestimate the benefit of PE participation-without PE competition, banks will likely bid with even lower prices, expanding the wedge with PE bidding prices.

\section{Bank Performance Post PE Acquisition}

The natural next question is: are PE investors able to successfully turn around the failed banks? In this section, we examine the post-acquisition performance of failed banks that are acquired by PE and by other banks. We also study the real effects by examining the economic recovery of regions in which the failed banks are acquired by PE investors. The performance of PE acquisitions compared to bank acquisitions is a priori unclear. On the one hand, PE investors do not have bankspecific operational experience or sources of synergies, which may lead to poorer performance. On the other hand, PE investors' experience in distressed investment and turnaround operations (Hotchkiss, Smith, and Strömberg, 2011), together with the steadier financing source (Bernstein, Lerner, and Mezzanotti, 2019), may be well-suited for the turnaround of failed banks in crisis.

\subsection{Quasi-Random Empirical Design}

To study failed banks' performance changes post acquisition by different buyers, a basic regression would simply compare the performance proxies in PE-acquired and bank-acquired banks post the acquisition event. This specification would be informative but masks the combination of i) the sorting of acquirer-target, as documented in the previous section, and ii) the treatment effect of PE acquisitions on the acquired banks.

\footnotetext{
${ }^{14}$ Federal Deposit Insurance Corporation (FDIC). 2017. Crisis and Response: An FDIC History, 2008-2013. Washington, DC: FDIC. p.xiii-xiv.
} 
An ideal experiment to isolate the effect of PE investors on post-acquisition performance would focus on a set of banks that are of interest to both PE investors and banks and for which the allocation to a PE investor or a bank is nearly random. We approximate this ideal experiment by exploiting a small set of banks where acquirer allocation can be viewed as quasi-random. We start from the sample of banks that were bid on by both PE investors and banks. We narrow down this sample to two sets of banks - those won by PE and at least one bank bid, and those won by a bank and at least one PE bid. We further require that in the auction the margin of victory of the winning $\mathrm{PE} /$ bank bidder over the closest losing bank/PE bid is small, within five percent to be precise. ${ }^{15}$ Our empirical strategy compares failed banks that were just won by the PE investors and those that were just won by the banks in this quasi-random sample.

In our main specification, we use a local linear regression approach (Gelman and Imbens, 2019):

$$
\text { Performance }_{b, i, t, z}=\alpha+\beta \cdot P E_{i}+\gamma \cdot \text { Control }_{i}+\theta_{t \times z}+\varepsilon_{i} .
$$

Performance is the performance of a branch $b$, located in region $z$, of bank $i$, that failed in year t. $P E$ is an indicator variable that equals one if the PE bidder won the auction and acquired the failed bank. $\theta_{t \times z}$ are region-by-time fixed effects controlling for the local time trends and are captured at the state-failed year level. Finer regional geographic delineation, say county-year, renders a very limited number of observations per group (on average 2.3 in each county-year unit), challenging the ability to correctly estimate the model. The analysis will later be adapted to other analytical units (like bank-level or region-level) by implementing the same logic, and aggregation details will be provided in subsections as we introduce the analysis.

\section{[Insert Table 5 Here.]}

The key identification assumption is that, for the specific subset of competitive auctions that we consider, whether a PE bidder wins or loses the bidding is “as good as” random. At first glance, out of the 48 acquisition deals that fall into our quasi-random sample, 25 were eventually acquired by a PE investor and 23 were eventually acquired by a bank-which suggests a fairly random pattern. Table 5 presents a balance test. We first examine whether bank-level characteristics differ between the bank-acquired and the PE-acquired samples. Among those characteristics shown to

${ }^{15}$ This approach is standard in the literature (Lee and Lemieux, 2010; Fisman et al., 2014; Colonnelli, Prem, and Teso, 2020). 
matter in broader selection, none seem to matter in this quasi-random sample. We also compare the variables that later will be used as performance proxies-these include branch, bank, or regional level information. Again, we do not find any significant differences across bank-acquired and PE-acquired samples.

In our quasi-random sample approach, our empirical strategy improves upon common approaches in the PE literature that tackle the identification challenge through building counterfactual cases using matching methods. ${ }^{16}$ Instead of assuming a matched firm that is equally selectable by PE, we leverage on the bidding setting in which PE bids and bank bids reveal their interests in selecting a publicly known target. Focusing on the sample of banks that are selectable and tightly bid on by both PE and banks further controls the selection effect.

One caveat is that even though this approach exploits a very tight control group, it is not a fully-specified regression discontinuity design in which we would better control for the microlevel variations in the bidding gaps (i.e., the running variable), which are unobserved by us. In our sample, the continuous bidding gap is coded to three categories by the FDIC-below five percent, five to ten percent, and above ten percent, while the underlying continuous variable is kept proprietary.

\subsection{Banks: Branch Closure and Deposits}

We first study bank performance post acquisition. The analysis focuses on the branch level for data observability reasons. Failed banks acquired by other banks are integrated into the acquiring institution, and it is thus difficult to observe standalone performance measures from standard sources such as the call reports. To overcome this problem, the approach in this section focuses on the performance of bank branches that can be tracked prior to and after the acquisitions.

Our first performance analysis concerns the closing of bank branches. Bank branch closure has important consequences for access to credit in the local economy and thus for financial stability. Nguyen (2019) shows that access to credit is very local, and bank branch closings lead to a persistent decline in local small business lending. This effect is particularly strong during the financial crisis.

${ }^{16}$ See, for example, Boucly, Sraer, and Thesmar (2011); Davis et al. (2014); Bernstein, Lerner, and Mezzanotti (2018); Fracassi, Previtero, and Sheen (2020). 
Our sample includes all bank branches owned by a failed bank at the time of failure. For the key outcome variable, we code whether the bank branch is closed within three years post acquisition using the FDIC Reports of Structure Changes. ${ }^{17}$ Control variables include those that have strong power in explaining PE investors' selection of acquisition-tier 1 risk-based capital ratio, core deposits to total deposits, C\&D loans to total loans, and OREO to total assets. Fixed effects are included at the failed year by state level. Standard errors are clustered at the level of failed bank acquirers, who make strategic decisions for bank operations.

\section{[Insert Table 6 Here.]}

Table 6 reports the results. Columns (1) and (2) are our preferred specifications using the quasi-random sample. In column (1), we consider a thought experiment in which two bank branches are located in the same geographic region (at the level of state) and whose parent banks failed in the same year. In this way, we take out the potential impact of timing, i.e., banks may have a different operational strategy during different periods in the crisis. We also take out the potential impact of the branch location, since branches located in regions hit harder by the crisis may be more likely to close. The -0.148 coefficient in column (1) means that bank branches acquired by PE investors are 14.8 percentage points less likely to be closed. This is a 73.6 percent decrease from the base branch closing rate of 20.1 percent across the full sample.

This result is particularly important for us to understand the role of PE acquisitions in stabilizing the local financial system, considering our earlier findings that PE-acquired banks tend to be located in regions with an unhealthy financial sector, as shown in Table 4. To better articulate this point, in column (2) we explore a new dependent variable to capture the cases of closing and exit from a county. This variable is coded as one if a PE-acquired bank branch closes and there is no other branch of the bank serving the county; alternatively, it is also coded as one if a bankacquired bank branch closes and there is no other branch of the bank nor an acquirer branch serving the county. The -0.070 coefficient suggests that PE acquired banks are less likely to close and exit a county they serve.

Column (2) also provides an opportunity to assess another potential force that could drive PEacquired banks' lower closing probability, which is that bank-acquired failed banks are more likely

${ }^{17}$ The results are robust to coding the closure variable over alternative time horizons. Most closures happen during the first three years. 
to close to retain limited branches in a region. In other words, bank acquirers may shut down an acquired branch because they already own one in the local area (i.e., consolidation of branches). The result in column (2) suggests that branches of bank-acquired failed banks have a higher frequency of closing, even for cases when the closure means a complete exit from the county.

In columns (3) and (4), we also report the regression with all bank branches as robustness checks. The results are similar. The point estimates for the PE effects are smaller in magnitude, which is consistent with the fact that PE investors, on average, acquire lower quality failed banks. Failing to account for this would underestimate the value-added by PE investors.

Next, we examine bank performance using the growth of deposits in local branches. Deposits are an important measure of bank performance, as they are related to the ability to lend and ultimately the ability to generate profit. Conceptually, the analysis appears to be simple to designwe would just compare the deposit growth of branches acquired by PE investors with those acquired by other banks. The challenge, however, is the active closing and consolidation of the bank-acquired branches. For example, assume there are two failed bank branches, A and B, in Durham County, NC, and that they are acquired by PE and another bank, respectively. Assume this acquiring bank has its own branch, labeled as C, in Durham. Branch B and C could have complex interactions post acquisition that make it inaccurate to simply track deposit levels at B or C. For example, branch C could completely absorb B, which would cause us to underestimate the level of deposits that B attracts.

Our first approach is to perform the analysis at the local county level and consider B and C jointly when evaluating the deposit growth. Specifically, our unit is at the bank-county level. The dependent variable is a failed bank's deposit change in the county region following the acquisition. For PE-acquired banks through shelf charters, this deposit change is for all branches in the local region; for bank-acquired banks and for PE acquisitions through inflatable charters or with multiple acquisitions, the deposit change is calculated using both the failed bank branches and the branches originally owned by the acquirer bank in order to account for the measurement issues that may arise from reorganization. ${ }^{18}$

\footnotetext{
${ }^{18}$ Note, we only keep counties where the failed bank did not completely exit, in which case the deposits would be -100 percent and which we have studied separately in Table 6.
} 


\section{[Insert Table 7 Here.]}

Table 7 presents the results. In columns (1) and (2), using the quasi-random sample, we show that within one year, there was little difference in the deposit-level changes-this makes sense given that changing failed bank operations takes time. This also provides additional assurance for our quasi-random experiment since there are not observable differences between PE- and bankacquired branches ex ante. As time goes by, the effect becomes stronger. In column (2), the comparisons are made by two failed banks' operations in the same county through the same period. PE-acquired banks have a higher three-year deposit growth by a magnitude of 35.6 percentage points. This economic magnitude is quite striking if we compare the three-year changes to the unconditional mean. Depending on the sample that we focus on, the averages of the deposit growth variables are negative as a national trend or only mildly positive.

In columns (3) and (4), we report results estimated using the full non-quasi-random sample. The results are qualitatively similar with milder quantitative magnitudes. As discussed in the branch closure analysis above, this is likely due to the fact that PE's acquisition strategy focuses on weaker banks to begin with, making it harder to detect a performance difference if such selection is not controlled for.

Of course, for most of the failed banks, the operations of the failed banks are combined with the acquirer's pre-existing bank operations (i.e., using the example, $\mathrm{B}$ and $\mathrm{C}$ are jointly considered). An alternative approach we take is to focus on a smaller sample of bank-county combinations in which the acquirer bank does not own an existing branch in the acquired failed bank's region. In other words, following the example, we study cases in which there is not a branch C. We report the results in Table 7 columns (5) and (6). After isolating the performance of the failed bank branches themselves, the PE-acquired banks still have higher deposit growth.

\subsection{Bank Lending and Local Recovery}

The banking sector plays an important role in the local economy. PE's ability to maintain branch operations and attract deposits thus leads to a natural hypothesis on whether the positive changes in bank branch operations also lead to better local economic recovery. We perform analysis at the county level using a model adapted from Eq. (2) but aggregated to the county level.

Essentially, we compare two counties with a failed bank branch in the same year (both of which were bid on by PE investors and banks), yet one bank branch was quasi-randomly allocated 
to an incumbent bank acquirer and one to a PE acquirer. The quasi-random design in this setting helps alleviate concerns about better performance arising mechanically because PE investors made purchases in worse-hit areas, and so a return to more "normal" conditions would look more dramatic for them. To cleanly identify the results, we also focus our sample on only counties that have one pure treatment, i.e., if a county has both bank acquisitions and PE acquisitions, we leave them outside the sample for empirical purposes.

[Insert Table 8 Here.]

Our first set of measures is about small business lending. Small business lending is an important function of local banks and creates important spillover effects for local economic growth. The analysis exploits both the extensive margin of small business lending and its intensive margin. Table 8 presents the results. In Panel A we use our preferred quasi-random sample. In column (1) we show that within the three years after a PE entity acquires a local bank, the number of small business lending deals experiences 32 percent faster growth compared to other counties. In column (2), we show that the increase in the total amount of small business lending is also higher in counties where the failed bank was acquired by PE.

The increase in the amount of small business lending could be partially related to the pricing of the loans. In column (3), we show that on average, the SBA loans are priced lower when PE investors intervene with the banks. The economic magnitude is roughly 32 basis points, which is five percent lower than the non-conditional mean of 6.4 percent as reported in Table 5. In column (4), we show that the average deal size increases only mildly, suggesting that the effect is more through the extension of credit to a larger number of small businesses rather than giving larger loans to a small set of small businesses. In Panel B, we report results using the full sample.

[Insert Table 9 Here.]

In Table 9 we present another set of regional variables that focus more on the recovery of local economic conditions. The analysis uses the same regression framework as in Table 8, and we also report analysis using both the quasi-random sample and the full sample. In columns (1) and (2), the outcome variables are job creation rates. We find that both the total number of jobs created and job creation in the startup sector are significantly higher in regions where the failed banks are acquired by PE investors. In columns (3) and (4), we move to examine the level of personal income. 
We find that the change in personal income is higher, both in terms of total personal income and the level of per capita income.

\subsection{Aggregate Loss Share Claims to the FDIC}

Another angle from which to examine the value of PE acquisition is by studying the cost of failed bank resolution incurred by the FDIC. Specifically, we are interested in whether PE-acquired banks claim more losses to the FDIC. The loss sharing agreements with the FDIC typically grant the failed bank acquirers a time window to claim a portion of losses from loan portfolios of the failed banks. Commercial loan portfolios have five years of loss share coverage, with an additional three years of reporting to share any recoveries. Single-family loan portfolios have 10 years of loss share coverage.

If PE-acquired banks perform more poorly in managing the loans in their covered portfolios, we would expect these banks to claim more losses to the FDIC. To test this, we use proprietary data from the FDIC on the total losses claimed by each acquirer with a loss sharing agreement on the failed bank portfolio. We aggregate the claim amounts made and paid out during the coverage period of the loss share agreement. This aggregated amount is then scaled by the total assets covered by the agreement to give us a measure of total claimed loss rates comparable across different banks.

\section{[Insert Table 10 Here.]}

Table 10 presents the results. After controlling for the fact that PE investors acquired less healthy banks using the selection variables, the estimated differences in claimed losses are virtually zero. In other words, PE investors do not appear to be costlier than other acquirers for the FDIC. We include results for both the total reported losses on the portfolio and the amount of the losses incurred by the acquirer net of loss sharing payments made to the acquirer by the FDIC. Note that when using our quasi-random sample for the analysis (columns 3 and 6), the number of observations drops to 38 banks that fall into our criterion and have loss coverage on their loan

portfolios. As a result, the analysis has low power, but it is reassuring that the economic magnitudes confirm prior results using the full sample.

\subsection{Exit of PE-acquired Failed Banks}

Private equity, as financial investors, are not in the business of permanently running a bank even though they were able to stabilize the acquired failed banks during the crisis period. How do 
they exit these investments, and how do these PE-acquired banks re-integrate into the banking sector? We hand collect information on the exit of PE-acquired banks from FDIC structure reports on bank merger activity. We obtain details on merger deal values, IPO activity, and any additional rounds of acquirer funding from S\&P Global Market Intelligence. Note that this analysis is more informative at the acquiring bank level (consortium level) because different failed banks are consolidated into one bank after being acquired by the same consortium under the same charter.

[Insert Table 11 Here.]

Out of 19 banks/consortia, 15 have been acquired or consolidated by other commercial banks, two went IPO, one is still under PE operations, and one was liquidated. ${ }^{19}$ We also report the banklevel counts that reflect the number of acquired failed banks in the acquiring consortia. Out of the 17 banks that were acquired or went IPO, PE investors held failed banks for 6.5 years on average. Interestingly, of the 15 acquisitions, 60 percent were acquired by a local bank-that is, a bank that overlaps with the footprint of the acquired bank at the zip code level. The number is even higher if we consider the banks to overlap at the county or state level.

This finding is consistent with the overall interpretation of what PE investors help achieve in this process. PE investors acquire failed banks that are too risky to acquire for incumbent banks who themselves may be in distress. Thus, PE investors fill the funding gap and turn around those banks with their hired expertise. These banks are later more suitable for a bank acquisition and return to traditional bank ownership. Slightly more than half of them are acquired by local banks, who were the natural buyers but were not necessarily in a good position at that time to make these acquisitions themselves.

We calculate the return by comparing consortium funds raised with exit prices. Ideally, we would hope to use the total cash disbursement, which is unobservable in some cases of our data. When these data are not available, we instead rely on the total committed capital to proxy for that cash disbursement component in IRR calculation. Given capital disbursement is lower than committed capital, our IRR calculation provides a lower bound of return calculation. We also supplement this with data on reported additional private placements or offerings from S\&P Global Market Intelligence, particularly when additional funds were raised to contribute to additional practices.

${ }^{19}$ One bank was liquidated by the acquirer after deposit insurance was terminated due to unsound banking 
failed bank purchases. Merger announced deal values are obtained from S\&P Global Market Intelligence as well. We find that the deal multiple is 2.11 on average and 2 at the median. We also calculate a rough IRR of $12 \%$ after accounting for the holding period, with adjustment for the interim additional funding. This is a good PE return: based on recent estimates from Brown et al. (2015), PE funds of similar vintages earned an IRR below 8\%.

\subsection{Management of PE-Acquired Failed Banks}

Taken together, evidence thus far paints a positive picture of the role of PE investors in stabilizing the financial system through participating in the process of failed bank resolution. A final question that we ask is: PE investors are not bankers, so how can PE intervention bring about those positive changes to the acquired failed banks? We attempt to answer this question by exploring the management human capital of the PE-acquired failed banks. We collect CEO backgrounds of the PE-acquired failed banks by hand from publicly available information on the internet, such as company bios, professional profiles, and featured articles.

[Insert Table 12 Here.]

Private equity investors hire ex-bankers to manage the acquired failed banks. Those bankers, on average, have nearly 30 years of experience in the banking industry, and more than half of them were CEOs of other banks before being appointed at the failed banks. More than 60 percent of the CEOs had experience in the local area of the failed bank, and nearly 70 percent of the hired bankers had experience working in a community bank. Interestingly, more than a third of the hired CEOs specialized in turnaround management and troubled and distressed assets.

\section{Conclusion}

This paper studies the role of private equity in stabilizing the financial system in the 2008 crisis through failed bank resolution. Using detailed and proprietary failed bank data from the FDIC combined with information on private equity investors, we provide the first empirical investigation of PE investors' role in failed bank resolution—an economically important but potentially controversial role.

An extensive literature explores the effects of private equity on firm-level outcomes, such as employment, productivity, product quality, and innovation. However, whether or not PE should 
be allowed in banking, one of the most central sectors in the financial system, has been an unexplored question. Our paper suggests that understanding the role of PE in the economy should take into broader account how the industry interacts with and affects the stability of the financial system. Further, our paper sheds light on the policy debate on whether to introduce private investors into the process of failed bank resolution.

We find that PE investors acquired failed banks that were generally underperforming and riskier than bank-acquired banks were. PE investors also acquired failed banks when the neighboring banks were also in distress and therefore had a lower ability to make failed bank acquisitions. Thus, our findings suggest that PE investors fill the capital gap in scenarios where the natural local bank buyers are themselves distressed or capital constrained. Using a quasirandom empirical design, we find that PE-acquired failed banks recovered as well as those acquired by banks despite being underperforming ex ante, and we show some evidence of them outperforming other distressed banks in various dimensions. Our quasi-random empirical design further shows positive real effects on the local economy of PE failed bank acquisitions. Overall, our results suggest a positive role for PE in helping to stabilize the financial system in the crisis through their participation in failed bank resolution. 


\section{References}

Acharya, Viral V., Hyun Song Shin, and Tanju Yorulmazer. 2011. Crisis resolution and bank liquidity, Review of Financial Studies 24: 2166-2205.

Acharya, Viral V., and Tanju Yorulmazer. 2008. Cash-in-the-market pricing and optimal resolution of bank failures, Review of Financial Studies 21: 2705-2742.

Berger, Allen N., and Christa HS Bouwman. 2013. How does capital affect bank performance during financial crises? Journal of Financial Economics 109 (1): 146-176.

Berger, Allen N., Anthony Saunders, Joseph M. Scalise, and Gregory F. Udell. 1998. The effects of bank mergers and acquisitions on small business lending, Journal of Financial Economics 50: $187-229$.

Berger, Allen N., and Gregory F. Udell. 1995. Relationship lending and lines of credit in small firm finance, Journal of Business 68: 351-382.

Bernanke, Ben S. 1983. Nonmonetary effects of the financial crisis in propagation of the great depression, American Economic Review 73, no. 3: 257-276.

Bernanke, Ben, and Gertler, Mark. 1990. Financial fragility and economic performance, Quarterly Journal of Economics 105:87-114.

Bernstein, Shai, Josh Lerner, and Filippo Mezzanotti. 2019. Private equity and financial fragility during the crisis, Review of Financial Studies 32(4): 1309-1373.

Bernstein, Shai, Josh Lerner, Morten Sorensen, and Per Strömberg. 2016. Private equity and industry performance, Management Science 63:1198-213.

Bernstein, Shai, and A. Sheen. 2016. The operational consequences of private equity buyouts: Evidence from the restaurant industry, Review of Financial Studies 29:2387-418.

Blundell-Wignall, Adrian. 2007. The private equity boom: Causes and policy issues, Financial Market Trends: Organization for Economic Cooperation and Development 92:59-86.

Boucly, Quentin, David Sraer, and David Thesmar. 2011. Growth LBOs, Journal of Financial Economics 102 (2): 432-453.

Brown, Gregory W., Robert S. Harris, Tim Jenkinson, Steven N. Kaplan, and David T. Robinson. 2015. What do different commercial data sets tell us about private equity performance? University of Chicago Working Paper.

Calder, Bobby, and Robert Burnkrant. 1977. Interpersonal influence on consumer behavior: An attribution theory approach, Journal of Consumer Research 4:29-38.

Che, Yeon-Koo, and Ian Gale. 2006. Revenue comparisons for auctions when bidders have arbitrary types, Theoretical Economics 1: 95-118.

Cohn, Jonathan B., Hotchkiss, Edith S., and Erin Towery. 2020. The motives for private equity buyouts of private firms: Evidence from U.S. corporate tax returns, Working Paper.

Colonnelli, Emanuele, Mounu Prem, and Edoardo Teso. 2020. Patronage and selection in public sector organizations, American Economic Review, Forthcoming. 
Cornett, Marcia Millon, and Hassan Tehranian. 1992. Changes in corporate performance associated with bank acquisitions, Journal of Financial Economics 31: 211-234.

Dam, Lammertjan, and Michael Koetter. 2012. Bank bailouts and moral hazard: Evidence from Germany, Review of Financial Studies 25: 2343-2380.

Davis, Steven, John Haltiwanger, Kyle Handley, Ron Jarmin, Josh Lerner, and Javier Miranda. 2014. Private equity, jobs, and productivity, American Economic Review 104:3956-90.

Davison, Lee K., and Ashley M. Carreon. 2010. Toward a long-term strategy for deposit insurance fund management, FDIC Quarterly 4: 29-37.

DeYoung, Robert, Michał Kowalik, and Gokhan Torna. 2018. Private equity investment in US banks, Working Paper.

Duchin, Ran, Oguzhan Ozbas, and Berk Sensoy. 2010. Costly external finance, corporate investment, and the subprime mortgage credit crisis, Journal of Financial Economics 97:418-35.

Eaton, Charlie, Sabrina T. Howell, and Constantine Yannelis. 2019. When investor incentives and consumer interests diverge: Private equity in higher education, Review of Financial Studies (10).

ECB. 2017. Guidance on leveraged transactions. Technical Report. https://www.bankingsupervision.europa.eu/ecb/pub/pdf/ssm.leveraged_transactions_guidanc e_201705.en.pdf

Fang, Lily, Victoria Ivashina, and Josh Lerner. 2013. Combining banking with private equity investing, Review of Financial Studies 26 (9): 2139-2173.

Fang, Lily, Victoria Ivashina, and Josh Lerner. 2015. The disintermediation of financial markets: Direct investing in private equity, Journal of Financial Economics 116:160-78.

Federal Deposit Insurance Corporation. 2009. Final Statement of Policy on Qualifications for Failed Bank Acquisitions. 74 Federal Register 45440-45449, September 2, 2009. https://www.fdic.gov/regulations/laws/federal/2009/09FinalSOP92.pdf.

Federal Deposit Insurance Corporation (FDIC). 2017. Crisis and Response: An FDIC History, 2008-2013. Washington, DC: FDIC.

Federal Deposit Insurance Corporation. 2018. Quarterly Banking Profile, Third Quarter 2018. https://www.fdic.gov/bank/analytical/qbp/timeseries/qbpnot.pdf.

Federal Deposit Insurance Corporation (FDIC). 2019. Resolutions Handbook, Revised January 15, 2019. https://www.fdic.gov/bank/historical/reshandbook/resolutions-handbook.pdf.

Fisman, Raymond, Florian Schulz, and Vikrant Vig. 2014. The private returns to public office, Journal of Political Economy 122 (4): 806-862.

Fracassi, Cesare, Alessandro Previtero, and Albert W. Sheen. 2020. Barbarians at the store? Private equity, products, and consumers, National Bureau of Economic Research, No. w27435.

Gandhi, Ashvin, YoungJun Song, and Prabhava Upadrashta. 2021. Private Equity, Consumers, and Competition: Evidence from the Nursing Home Industry, Working Paper. 
Gelman, Andrew, and Guido Imbens. 2019. Why high-order polynomials should not be used in regression discontinuity designs, Journal of Business \& Economic Statistics 37 (3): 447-456.

Gilje, Erik P., Elena Loutskina, and Philip E. Strahan. 2013. Exporting liquidity: Branch banking and financial integration, Journal of Finance 71: 1159-1184.

Goergen, Marc, Noel O’Sullivan, and Geoff Wood. 2011. Private equity takeovers and employment in the UK: Some empirical evidence, Corporate Governance: An International Review 19:259-75.

Gompers, Paul, Steven Kaplan, and Vladimir Mukharlyamov. 2016. What do private equity firms say they do? Journal of Financial Economics 121:449-76.

Gompers, Paul, Kristin Mugford, and Daniel Kim. 2012. Bain Capital: Outback Steakhouse, Harvard Business School Case no. 212-087.

Gorton, Gary, and Andrew Winton. 2003. Financial intermediation. In Handbook of the Economics of Finance, vol. 1, pp. 431-552. Elsevier.

Granja, Joao. 2013. The relation between bank resolutions and information environment: Evidence from the auctions for failed banks, Journal of Accounting Research 51: 1031-1070.

Granja, Joao, Gregor Matvos, and Amit Seru. 2017. Selling failed banks, Journal of Finance 72(4): 1723-1784.

Gupta, Atul, Sabrina T. Howell, Constantine Yannelis, and Abhinav Gupta. 2021. Does private equity investment in healthcare benefit patients? Evidence from nursing homes, National Bureau of Economic Research, No. w28474.

Hoshi, Takeo, Anil Kashyap, and David Scharfstein. 1990. The role of banks in reducing the costs of financial distress in Japan, Journal of Financial Economics 27:67-88.

Hoshi, Takeo, Anil Kashyap, and David Scharfstein. 1991. Corporate structure, liquidity, and investment: Evidence from Japanese industrial groups, Quarterly Journal of Economics 106:33-60.

Houston, Joel F., and Michael D. Ryngaert. 1994. The overall gains from large bank mergers, Journal of Banking \& Finance 18: 1155-1176.

Hotchkiss, Edie, David C. Smith, and Per Strömberg. 2011. Private equity and the resolution of financial distress.

Hynes, Richard M., and Steven D. Walt. 2010. Why banks are not allowed in bankruptcy, Washington \& Lee Law Review 67: 985-1051.

Illig, Robert. 2012. The dog that didn't bark: Private investment funds and relational contracts in the wake of the Great Recession, Michigan Journal of Private Equity \& Venture Capital Law 2:49-95.

Ivashina, Victoria, and Anna Kovner. 2011. The private equity advantage: Leveraged buyout firms and relationship banking, Review of Financial Studies 24:2462-98.

Ivashina, Victoria, and David Scharfstein. 2010. Bank lending during the financial crisis of 2008, Journal of Financial Economics 97:319-38. 
James, Christopher. 1987. Some evidence on the uniqueness of bank loans, Journal of Financial Economics 19: 217-235.

James, Christopher. 1991. The losses realized in bank failures, Journal of Finance 46: 12231242.

James, Christopher, and Peggy Wier. 1987. An analysis of FDIC failed bank auctions, Journal of Monetary Economics 20: 141-153.

Jensen, Michael. 1989. The eclipse of the public corporation, Harvard Business Review no. 5: 61-74.

Jiang, Wei, Kai Li, and Wei Wang. 2012. Hedge funds and Chapter 11, Journal of Finance 67 (2): 513-560.

John, Kose, Larry Lang, and Jeffry Netter. 1992. The voluntary restructuring of large firms in response to performance decline, Journal of Finance 47:891-917.

Kahle, Kathleen, and Rene Stulz. 2013. Access to capital, investment, and the financial crisis, Journal of Financial Economics 110:280-99.

Kaplan, Steven. 1989. The effects of management buyouts on operating performance and value, Journal of Financial Economics 24:217-54.

Kaplan, Steven, and Jeremy Stein. 1993. The evolution of buyout pricing and financial structure in the 1980s, Quarterly Journal of Economics 108:313-57.

Kaplan, Steven, and Per Strömberg. 2009. Leveraged buyouts and private equity, Journal of Economic Perspectives 23:121-46.

Kirti, Divya, and Natasha Sarin. 2020. Private equity value creation in finance: Evidence from life insurance, U of Penn, Inst for Law \& Econ Research Paper 20-17.

Lee, David S., and Thomas Lemieux. 2010. Regression discontinuity designs in economics, Journal of Economic Literature 48 (2): 281-355.

Lerner, Josh, Morten Sorensen, and Per Strömberg. 2011. Private equity and long-run investment: The case of innovation, Journal of Finance 66 (2): 445-477.

Lichtenberg, Frank, and Donald Siegel. 1990. The effects of leveraged buyouts on productivity and related aspects of firm behavior, Journal of Financial Economics 27:165-94.

Michaely, Roni, and Michael Roberts. 2012. Corporate dividend policies: Lessons from private firms, Review of Financial Studies 25:711-46.

Nguyen, Hoai-Luu Q. 2019. Are credit markets still local? Evidence from bank branch closings, American Economic Journal: Applied Economics 11 (1): 1-32.

Office of the Comptroller of the Currency, "OCC Conditionally Approves First National Bank Shelf Charter to Expand Pool of Qualified Bidders for Troubled Institutions,” NR 2008-137, November 21, 2008, https://www.occ.gov/news-issuances/news-releases/2008/nr-occ-2008137.html.

Petersen, Mitchell, and Raghuram Rajan. 1994. The benefits of lending relationships: Evidence from small business data, Journal of Finance 49:3-37. 
Petersen, Mitchell, and Raghuram Rajan. 2002. Does distance still matter? The information revolution in small business lending, Journal of Finance 57: 2533-2570

Rajan, Raghuram. 1992. Insiders and outsiders: The choice between informed and arm's- length debt, Journal of Finance 47: 1367-1400.

Rajan, Raghuram, and Luigi Zingales. 1998. Financial dependence and growth, American Economic Review 88:559-86.

Stein, Jeremy C. 2002. Information production and capital allocation: Decentralized versus hierarchical firms, Journal of Finance 57: 1891-1921.

Vij, Siddharth. 2020. Acquiring failed banks, Working Paper. 


\section{Appendix 1. Variable Definition and Description}

\begin{tabular}{|c|c|}
\hline Variable & Definition and Description \\
\hline Asset size (in \$Million) & $\begin{array}{l}\text { Total assets. Sum of all assets owned by the institution including cash, } \\
\text { loans, securities, bank premises and other assets. }\end{array}$ \\
\hline $\begin{array}{l}\% \text { Tier } 1 \text { risk-based } \\
\text { capital ratio }\end{array}$ & $\begin{array}{l}\text { Tier } 1 \text { capital divided by adjusted average assets (\%). Tier } 1 \text { capital } \\
\text { includes common equity plus noncumulative preferred stock plus } \\
\text { minority interests in consolidated subsidiaries less goodwill and other } \\
\text { ineligible intangible assets. Adjusted average assets are average total } \\
\text { assets minus disallowed intangibles. }\end{array}$ \\
\hline Liquidity ratio & $\begin{array}{l}\text { Sum of cash, fed funds sold, and securities, excluding mortgage-backed } \\
\text { securities, divided by total assets. }\end{array}$ \\
\hline $\begin{array}{l}\text { Core deposits to total } \\
\text { deposits }\end{array}$ & $\begin{array}{l}\text { Total domestic deposits minus time deposits of more than } \$ 250,000 \text { and } \\
\text { brokered deposits of } \$ 250,000 \text { or less, divided by total deposits. }\end{array}$ \\
\hline Net interest margin (\%) & $\begin{array}{l}\text { Quarterly net interest income as a percent of a two-period average } \\
\text { earning assets. }\end{array}$ \\
\hline $\begin{array}{l}\text { CRE loans to total } \\
\text { loans }\end{array}$ & $\begin{array}{l}\text { Ratio of commercial real estate (CRE) loans to total loan and lease } \\
\text { financing receivables. Includes all nonfarm, nonresidential properties } \\
\text { secured by real estate and multifamily ( } 5 \text { or more) residential properties } \\
\text { secured by real estate held in domestic offices. }\end{array}$ \\
\hline $\begin{array}{l}C \& D \text { loans to total } \\
\text { loans }\end{array}$ & $\begin{array}{l}\text { Ratio of construction and development loans (C\&D) to total loans and } \\
\text { lease financing receivables. Includes all construction and land } \\
\text { development loans secured by real estate held in domestic offices. }\end{array}$ \\
\hline $\begin{array}{l}\text { C\&I loans to total } \\
\text { loans }\end{array}$ & $\begin{array}{l}\text { Ratio of commercial and industrial (C\&I) loans to total loans and lease } \\
\text { financing receivables. }\end{array}$ \\
\hline $\begin{array}{l}\text { Residential loans to } \\
\text { total loans }\end{array}$ & $\begin{array}{l}\text { Ratio of total loans secured by 1-4 family residential properties held in } \\
\text { domestic offices to total loans and lease financing receivables. }\end{array}$ \\
\hline $\begin{array}{l}\text { Consumer loans to } \\
\text { total loans }\end{array}$ & $\begin{array}{l}\text { Ratio of loans to individuals for household, family, and other personal } \\
\text { expenditures to total loans and lease financing receivables. }\end{array}$ \\
\hline $\begin{array}{l}\text { Noncurrent loans to } \\
\text { total loans }\end{array}$ & $\begin{array}{l}\text { Ratio of noncurrent loans and leases to gross loans and leases. Includes } \\
\text { total loan and lease financing receivables } 90 \text { days or more past due and in } \\
\text { nonaccrual status. }\end{array}$ \\
\hline OREO to total assets & $\begin{array}{l}\text { Ratio of other real estate owned to total assets. Includes real estate } \\
\text { acquired and direct and indirect investments in real estate. }\end{array}$ \\
\hline $\begin{array}{l}\text { Loss-sharing } \\
\text { agreement }\end{array}$ & $\begin{array}{l}\text { Agreement between the FDIC and a failed bank acquirer in which the } \\
\text { FDIC absorbs a portion of the losses on a specified pool of assets. }\end{array}$ \\
\hline $\begin{array}{l}\text { Neighbor \% tier } 1 \text { risk- } \\
\text { based capital ratio }\end{array}$ & $\begin{array}{l}\text { Mean tier } 1 \text { risk-based capital ratio for banks that share at least one } \\
\text { branch zip code with the focal bank (\%). }\end{array}$ \\
\hline
\end{tabular}


Neighbor noncurrent

loans to total loans

Neighbor OREO to

total assets

No of local banks

(>3xSize)

No of failed banks in state
Mean noncurrent loans to total loans for banks that share at least one branch zip code with the focal bank.

Mean other real estate owned to total assets for banks that share at least one branch zip code with the focal bank.

Number of local banks at least three times the size and sharing at least one branch zip code with the focal bank.

Number of failed banks in state where focal bank headquarters is located. 


\section{Appendix 2. Institutional Details-The General Process of Failed Bank Resolution}

Bank resolution activities are initiated by a failing bank letter to the FDIC from federal and state banking regulators who monitor the financial condition of banks. Such initiation is triggered when a banking institution becomes critically undercapitalized or insolvent. ${ }^{20}$

The FDIC then contacts the management of the failing depository institution. The FDIC also engages a third-party financial advisor to conduct a review of the assets and compile initial information. Importantly, in this review process, the financial advisor estimates a loss factor for each asset category using an identified sample of assets. This information is further used by the FDIC to set the reservation value on the subsequent resolution of the depository institution.

During the financial crisis, the FDIC used the Purchase and Assumption (P\&A) resolution method in roughly 95 percent of the cases, and these are the transactions studied in this paper. In a P\&A transaction, the FDIC uses a process that resembles a first-price sealed bid auction to sell some or all of the assets and liabilities of the depository institution. Only in cases when the auction does not generate any bidding or when the highest bid is below the FDIC's reservation value will the FDIC use an alternative resolution method. The resolution process can be categorized into four steps: marketing and identifying the bidder pool, providing information, bidding, and resolution.

The first step of selling failed banks is to identify a pool of potential buyers that have expressed interest in bidding on failed institutions and that satisfy a list of requirements. To be approved to bid in a P\&A transaction, the potential bidder must be a chartered financial institution or an investor group that has received a conditional charter or is in the process of obtaining a "de novo" charter. PE investors fall into the latter category of "investor group" as bidders. Moreover, the bidding financial institution must be well capitalized and possess a CAMELS ${ }^{21}$ rating of 1 or 2, a satisfactory Community Reinvestment Act (CRA) rating, and a satisfactory anti-money-laundering record.

In the second step, eligible bidders receive notification of an acquisition opportunity, and those who are interested in pursuing the opportunity must sign a confidentiality agreement. The FDIC then provides eligible bidders with an information package on the failed institution. The information contains loan reviews, schedules representing the value of the items on the failed bank's balance sheet, and operational

\footnotetext{
${ }^{20}$ A bank is deemed by regulators to be critically undercapitalized when the ratio of tangible equity to total assets is at or below 2 percent. Tangible equity is the amount of tier 1 capital plus outstanding non-tier 1 perpetual preferred stock.

${ }^{21}$ CAMELS is short for (C)apital Adequacy, (A)sset quality, (M)anagement, (E)arnings, (L)iquidity, and (S)ensitivity to market risk. CAMELS ratings are assigned by bank supervisors after an on-site examination at each bank.
} 
information. As part of their onsite due diligence, potential bidders can request to review the individual loan documents.

In the third step, the formal bidding, the process generally starts 12 to 15 days before the scheduled closing of the failed bank. Bidders can place one or more sealed bids for the failed bank. The FDIC then chooses the bid that is least costly to the Deposit Insurance Fund (DIF) ${ }^{22}$ after evaluating all submitted bids using its proprietary least-cost test model. The FDIC selects the bid whose terms entail the leastestimated cost for the DIF if those costs are below the reservation value set by the FDIC, which is unknown to bidders. Bids are not submitted as a single “price," but rather they frequently vary along multiple dimensions for each bid. For example, these pricing dimensions can include the amount of discount applied to the assets, the premium paid for deposits, the amount and types of assets acquired, the type of transaction for purchase (whole bank, loss share, etc.), the extent of any coverage for shared losses, and so on. The least cost test must take all of these factors into account when estimating the resolution cost associated with each bid for comparison.

In the final step, i.e., when a failing depository institution enters receivership, the FDIC takes custody of the failed bank's premises, records, loans, and other assets. The priority for paying allowed claims is given to depositors, including the FDIC as subrogee, over other general and unsecured creditors. The DIF took a loss on most bank failures that occurred during the recent financial crisis, suggesting that the receivership proceeds do not cover the FDIC's subrogated claim and that the FDIC is the residual claimant in most receiverships (Hynes and Walt, 2010). Between 2008 and 2013, the DIF lost approximately \$73 billion due to depository institution failures. ${ }^{23}$ The fund reached a negative balance on an accounting basis during the third quarter of 2009. It has since recovered and stood at $\$ 100$ billion at the end of 2018, resulting in a reserve ratio of 1.36 percent. ${ }^{24}$ The FDIC responded to the large losses on its DIF by collecting a special assessment of 5bps on all depository institutions and requiring prepaid assessments to boost the fund's liquidity. In addition, the FDIC updated its risk-based pricing for deposit insurance. ${ }^{25}$

\footnotetext{
22 This is mandated by The Federal Deposit Insurance Corporation Improvement Act (FDICIA) of 1991.

${ }^{23}$ Federal Deposit Insurance Corporation (FDIC). 2017. Crisis and Response: An FDIC History, 2008-2013. Washington, DC: FDIC. p.xiii.

${ }^{24}$ Quarterly Banking Profile, Third Quarter 2018. https://www.fdic.gov/bank/analytical/qbp/2018sep/qbp.pdf.

${ }^{25}$ Federal Deposit Insurance Corporation (FDIC). 2017. Crisis and Response: An FDIC History, 2008-2013. Washington, DC: FDIC. Chapter 5.
} 


\section{Figure 1. Bank Failures over Time}

This figure plots the time series of bank failures irrespective of resolution method and acquirer type during the period 2000 to 2018 . Data are from the Federal Deposit Insurance Corporation and are available at https://www.fdic.gov/bank/individual/failed/banklist.html. The time series includes the failed banks whose resolution process was a P\&A transaction or a deposit payoff, but does not include open bank assistance. In Panel (A) we plot the total number of bank failures, and in Panel (B) we plot the total assets (in Billion USD) at failure.

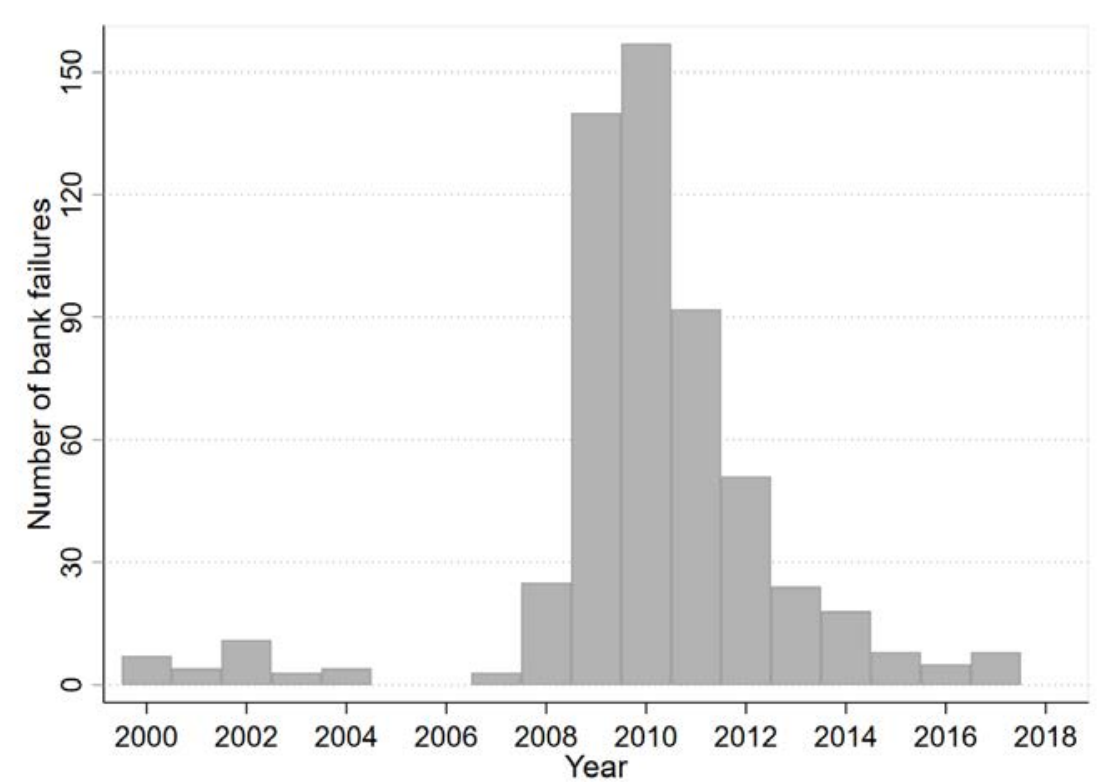

Panel (A)

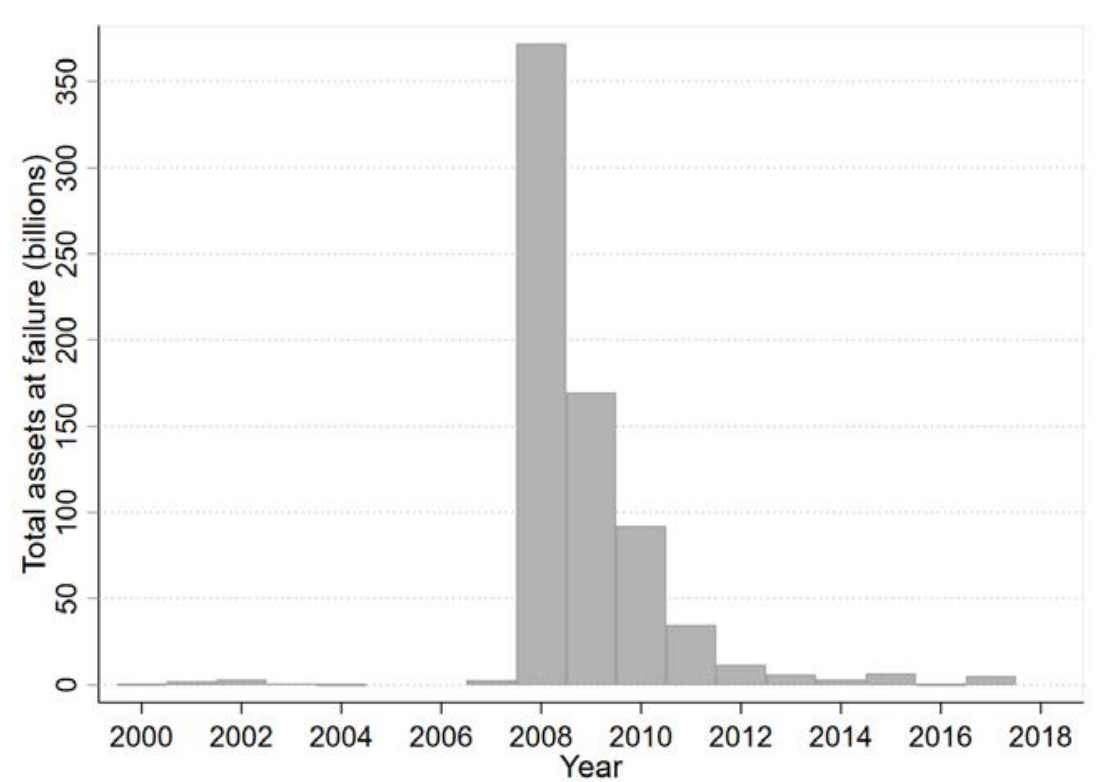

Panel (B) 
Figure 2. Illustrative Flow Chart of Failed Bank Resolution and PE Participation

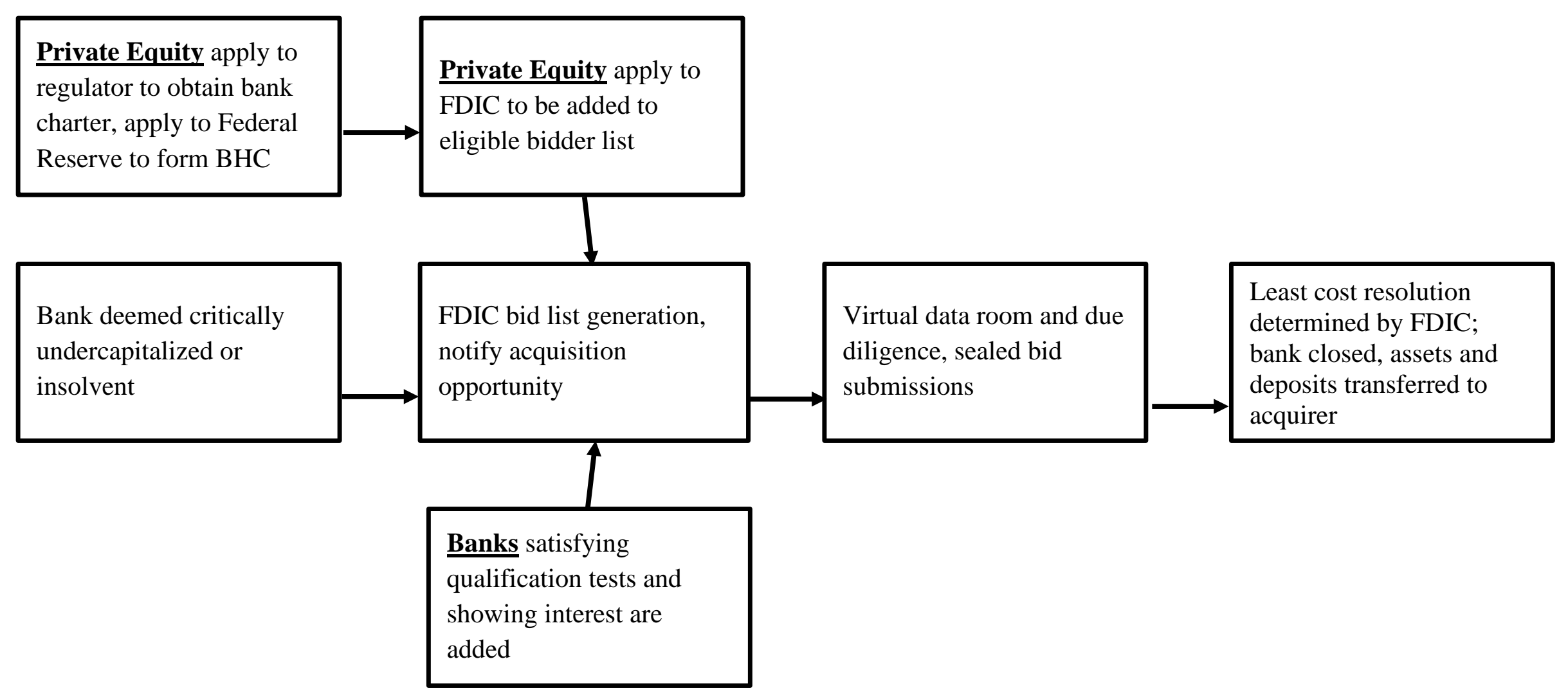




\section{Figure 3. PE Participation in Failed Bank Acquisitions}

This figure shows the number of failed banks acquired by other banks and by PE during 2009-2014. Panel (A) is plotted based on the number of failed bank acquisitions. Panel (B) is based on the total assets acquired. Years 2009-2014 are active years for PE acquisitions during the crisis. Prior to 2008, PE acquirers were not yet allowed to participate in failed bank auctions, and 2009 was the first successful PE acquisition. After 2014, they were allowed to participate but no PE acquisitions of failed banks were made.

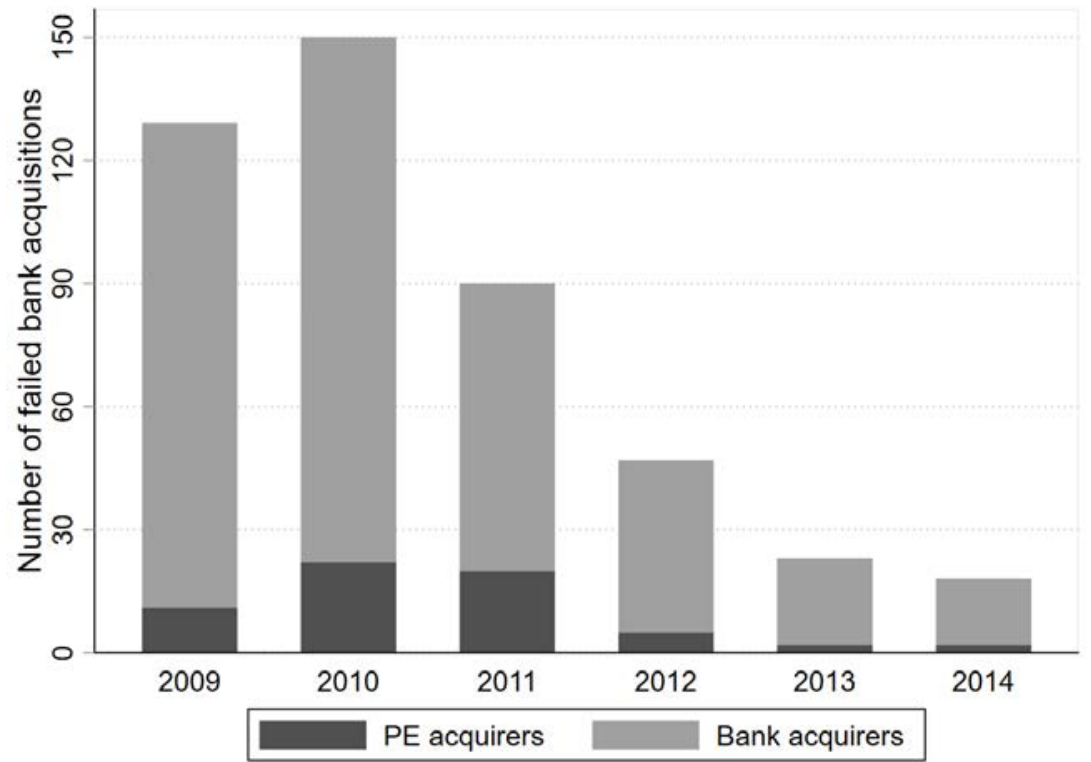

Panel (A)

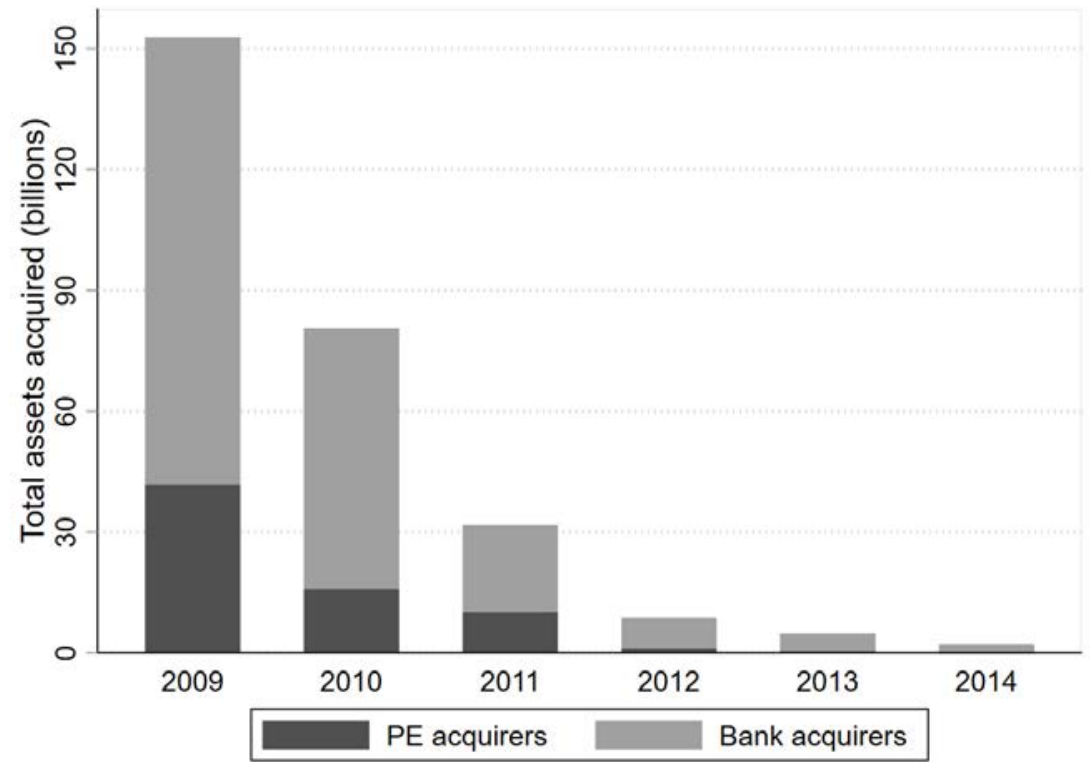

Panel (B) 


\section{Figure 4. Comparing Banks in Different Acquisition Groups}

This figure presents the characteristics of failed banks (and those of their neighboring banks) targeted by different pools of acquirers: those that were bid on and eventually acquired by PE investors, those bid on by PE investors but may eventually be won by a PE investor or an incumbent bank, and those that were only bid on and eventually acquired by other incumbent banks. For each characteristic, we present the sample mean across the three groups.

Panel (A): Sorting on Failed Banks’ Own Characteristics
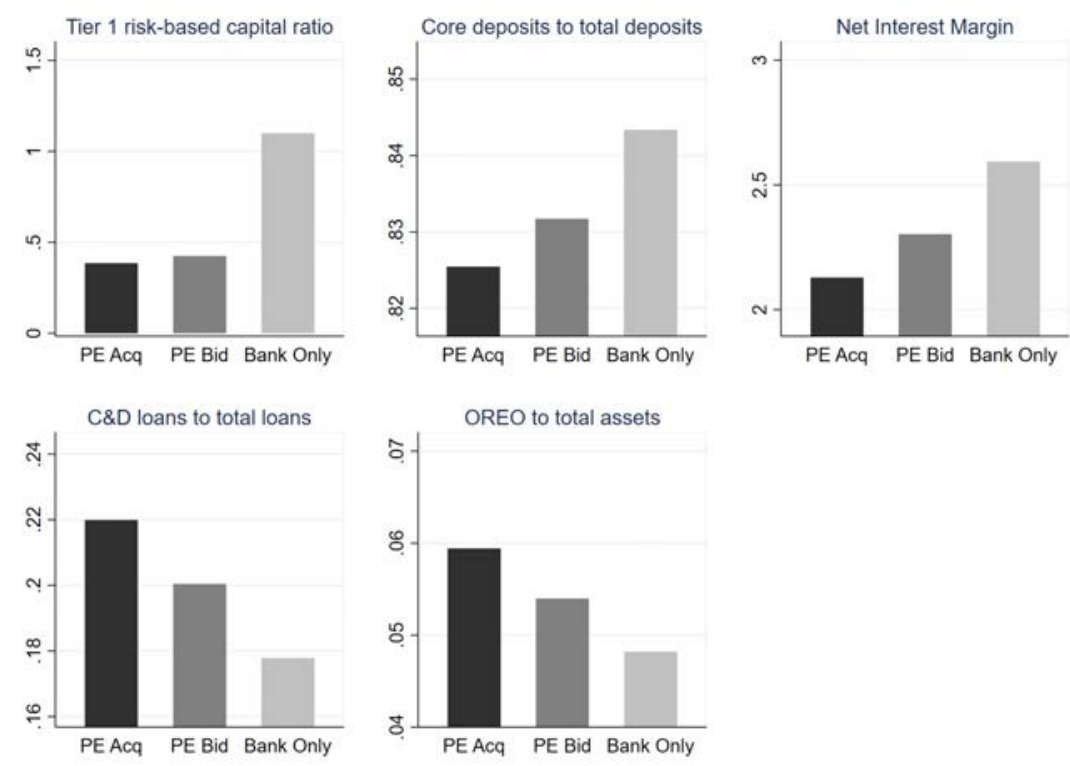

Panel (B): Sorting on Neighboring Banks’ Characteristics
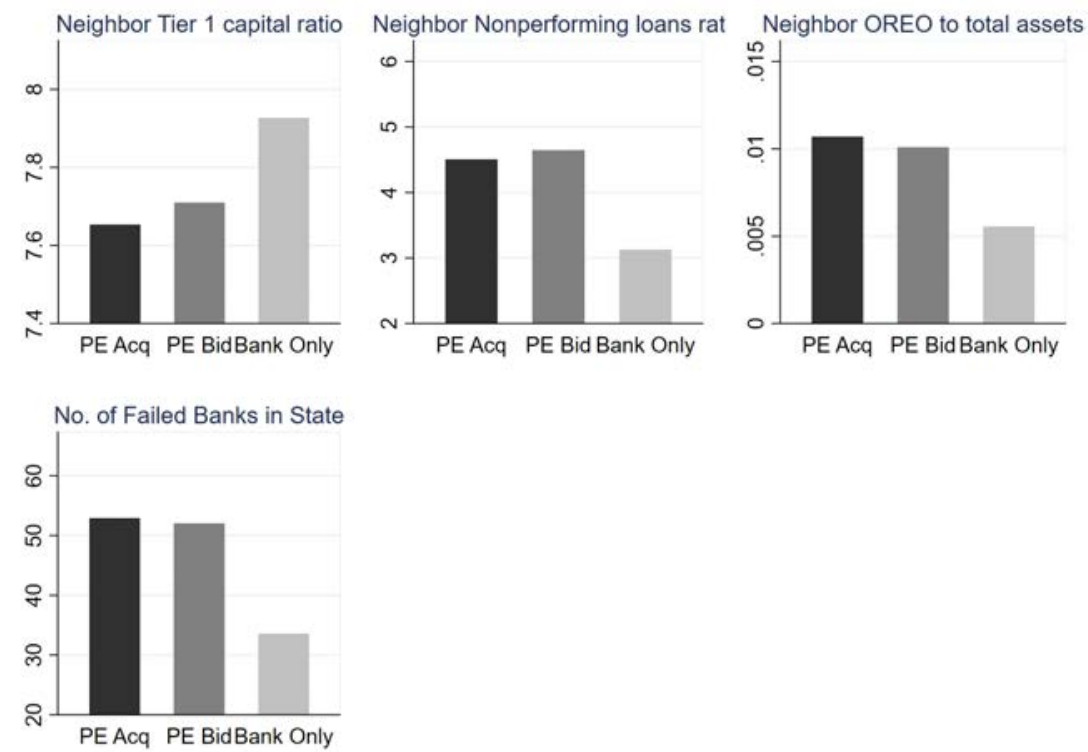


\section{Table 1. Summary Statistics for the Private Equity Buyers}

This table presents summary statistics of the PE buyers in failed bank acquisitions. We report the summary statistics at the consortia level and PE fund level. Consortia are the groups of PE investors that collaborate in acquiring failed banks, and consortia-level information is collected from the FDIC. Of the 20 distinct PE charters, one acquirer purchased failed banks under two separate charters that were then consolidated and is counted as a single consortium in the data below. PE-level information is collected from Preqin. For each variable, we report mean, standard deviation, and $25^{\text {th }}, 50^{\text {th }}$, and $75^{\text {th }}$ percentiles.

\begin{tabular}{lccccc}
\hline & Mean & $\begin{array}{c}\text { Standard } \\
\text { Deviation }\end{array}$ & $\begin{array}{c}25^{\text {th }} \\
\text { Percentile }\end{array}$ & Median & $\begin{array}{c}7^{\text {th }} \\
\text { Percentile }\end{array}$ \\
\cline { 2 - 6 } Consortium-Level (N=19) & & & & & \\
Number of PE firms per consortium & 3.37 & 2.29 & 2 & 4 & 4.5 \\
Share of PE ownership in consortium ${ }^{26}$ & 68.9 & 35.5 & 62 & 76 & 100 \\
Total number of failed banks bid on & 5.2 & 4.18 & 1.75 & 3 & 8 \\
Number of states (bids) & 1.32 & 0.82 & 1 & 1 & 1 \\
Number of acquisitions (bid and “win”) & 3.26 & 3.07 & 1 & 2 & 4 \\
Number of states (acquisitions) & 1.26 & 0.56 & 1 & 1 & 1 \\
Prior experience in financial distress & 0.58 & 0.51 & 0 & 1 & 1 \\
Private Equity Level (N=42, available on Preqin) & & & & 2009 \\
Fund vintage & 2007.52 & 2.95 & 2006 & 2007 & 3100.00 \\
Fund size (million USD) & 2724.21 & 4075.23 & 654.05 & 1393.15 & 0 \\
First-time fund (0 or 1) & 0.18 & 0.39 & 0 & 0 & 0 \\
\hline
\end{tabular}

\footnotetext{
${ }^{26} \mathrm{PE}$ ownership shares include three acquisitions that occurred through non-bank charters but are exceptions in their funding structure. Of these, two were small banks acquired by single investors, and one was a community development bank with funding provided by large institutional investors. We count those PE ownership shares as zero in the above table. Excluding these banks results in a mean PE ownership share of 82 percent and a median of 85 percent.
} 


\section{Table 2. Summary Statistics of the Failed Banks}

This table presents summary statistics for failed banks between 2009 and 2014. Variables are obtained from the Call Report submitted by the failed bank in the quarter prior to failure. Asset size is the amount of assets at the failed bank in millions. \% Tier 1 risk-based capital is the tier 1 risk-based capital divided by adjusted average assets, as a percentage. Liquidity ratio is the sum of cash, fed funds sold and securities, excluding mortgage-backed securities, divided by total assets. Core deposits to total deposits is total domestic deposits minus time deposits of more than $\$ 250,000$ and brokered deposits of $\$ 250,000$ or less, divided by total deposits. Net interest margin (\%) is the quarterly net interest income as a percent of a two-period average earning assets. CRE loans to total loans is non-farm, non-residential properties secured by real estate and multifamily ( 5 or more) residential properties secured by real estate, divided by total loans. $C \& D$ loans to total loans is construction and land development loans secured by real estate divided by total loans. C\&I loans to total loans is commercial and industrial loans, divided by total loans. Consumer loans to total loans is loans to individuals for household, family, and other personal expenditures, divided by total loans. Residential loans to total loans is loans secured by 1-4 family residential properties, divided by total loans. Noncurrent loans to total loans is the ratio of noncurrent loans to total loans. OREO to total assets is the ratio of other real estate owned to total assets. Loss sharing agreement is an indicator variable that is equal to 1 if the P\&A in resolution included an agreement for the FDIC to partially indemnify losses incurred on covered assets. Neighboring and local bank variables are constructed as the mean of banks that share at least one branch zip code with the focal bank. No of failed banks in state is defined as the number of failed banks located in the same state as the headquarters of the failed bank.

\begin{tabular}{|c|c|c|c|c|c|}
\hline$N=456$ & Mean & $\begin{array}{c}\text { Standard } \\
\text { Deviation }\end{array}$ & $\begin{array}{c}25^{\text {th }} \\
\text { Percentile }\end{array}$ & Median & $\begin{array}{c}75^{\text {th }} \\
\text { Percentile }\end{array}$ \\
\hline \multicolumn{6}{|l|}{ Failed bank characteristics } \\
\hline Asset size (\$ millions) & 727.0 & 2,352 & 101.7 & 207.4 & 461.2 \\
\hline \% Tier 1 risk-based capital to total assets & 0.925 & 2.698 & 0.155 & 1.105 & 1.995 \\
\hline Liquidity ratio & 0.168 & 0.082 & 0.110 & 0.156 & 0.211 \\
\hline Core deposits to total deposits & 0.837 & 0.145 & 0.742 & 0.878 & 0.958 \\
\hline Net interest margin (\%) & 2.550 & 1.248 & 1.850 & 2.560 & 3.285 \\
\hline CRE loans to total loans & 0.387 & 0.170 & 0.272 & 0.379 & 0.491 \\
\hline Construction and development loans to total loans & 0.186 & 0.137 & 0.0842 & 0.158 & 0.261 \\
\hline C\&I loans to total loans & 0.107 & 0.089 & 0.044 & 0.083 & 0.143 \\
\hline Consumer loans to total loans & 0.023 & 0.040 & 0.004 & 0.012 & 0.027 \\
\hline Residential loans to total loans & 0.259 & 0.184 & 0.127 & 0.231 & 0.326 \\
\hline Noncurrent loans to total loans & 0.164 & 0.095 & 0.097 & 0.150 & 0.203 \\
\hline OREO to total assets & 0.052 & 0.049 & 0.017 & 0.039 & 0.071 \\
\hline Loss-sharing agreement (Yes/No) & 0.662 & 0.473 & 0 & 1 & 1 \\
\hline \multicolumn{6}{|l|}{ Neighboring bank conditions } \\
\hline Neighbor \% tier 1 risk-based capital ratio & 7.930 & 1.340 & 7.133 & 7.945 & 8.650 \\
\hline Neighbor noncurrent loans to total loans & 0.036 & 0.035 & 0.009 & 0.024 & 0.053 \\
\hline Neighbor OREO to total assets & 0.007 & 0.010 & 0.001 & 0.003 & 0.009 \\
\hline No. of local banks (>3xSize) & 2.877 & 2.259 & 1 & 2 & 4 \\
\hline No. of failed banks in state & 37.41 & 28.75 & 8 & 35 & 69 \\
\hline
\end{tabular}




\section{Table 3. Characteristics of PE-Acquired Failed Banks}

This table presents the estimation results from a logit regression framework in the following form:

$$
\operatorname{Pr}(P E \text { Acquired }=1)=\Phi\left(\alpha+\beta \cdot X_{i}+\gamma \cdot \text { Control }_{i}+\theta_{t}+\varepsilon_{i}\right) .
$$

The analysis is performed on the cross-sectional sample of all failed banks that were eventually acquired by a bank or a private equity consortium. The dependent variable is a dummy that takes value 1 if the failed bank was eventually acquired by PE and 0 otherwise (i.e., acquired by a bank). Panel A investigates characteristics of the failed banks themselves. Panel B investigates characteristics of the neighboring banks of the focal failed bank. All variables are defined in Table 2 and in the appendix of variable definition. We control for the size of the bank using the logarithm of the total assets of the bank. Failed Year-Quarter fixed effects are included to account for the timevarying economic and regulatory environments that could affect the failed bank resolution process. Robust standard errors are displayed in parentheses. ${ }^{* *},{ }^{* *}$, and $*$ indicate significance at the $1 \%, 5 \%$, and $10 \%$ levels, respectively.

Panel A: Characteristics of Failed Banks and PE Acquisitions

(2)

(3)

(4)

I(PE Acquired)

\begin{tabular}{|c|c|c|c|c|c|}
\hline \% Tier 1 risk-based capital ratio & $\begin{array}{c}-0.013^{* * *} \\
(0.005)\end{array}$ & & & & \\
\hline Core deposits to total deposits & & $\begin{array}{c}-0.220^{* *} \\
(0.103)\end{array}$ & & & \\
\hline Net interest margin (\%) & & & $\begin{array}{c}-0.054^{* * *} \\
(0.012)\end{array}$ & & \\
\hline C\&D loans to total loans & & & & $\begin{array}{l}0.229 * \\
(0.123)\end{array}$ & \\
\hline OREO to total assets & & & & & $\begin{array}{c}0.626 * * \\
(0.253)\end{array}$ \\
\hline Log(asset in $\$ 000$ ) & $\begin{array}{c}0.057 * * * \\
(0.011)\end{array}$ & $\begin{array}{c}0.052 * * * \\
(0.011)\end{array}$ & $\begin{array}{c}0.044^{* * *} \\
(0.009)\end{array}$ & $\begin{array}{c}0.052^{* * *} \\
(0.012)\end{array}$ & $\begin{array}{c}0.058 * * * \\
(0.011)\end{array}$ \\
\hline Observations & 456 & 456 & 456 & 456 & 456 \\
\hline Failed Year-Quarter FE & Yes & Yes & Yes & Yes & Yes \\
\hline Pseudo R-squared & 0.181 & 0.170 & 0.218 & 0.172 & 0.175 \\
\hline
\end{tabular}


Panel B: Financial Health of Neighbor Banks and PE Acquisitions

\begin{tabular}{|c|c|c|c|c|c|}
\hline & (1) & (2) & $\begin{array}{c}\text { (3) } \\
\text { (PE Acquired }\end{array}$ & (4) & (5) \\
\hline Neighbor \% tier 1 risk-based capital ratio & $\begin{array}{l}-0.020^{*} \\
(0.012)\end{array}$ & & & & \\
\hline Neighbor noncurrent loans to total loans & & $\begin{array}{c}0.825^{* * *} \\
(0.319)\end{array}$ & & & \\
\hline Neighbor OREO to total assets & & & $\begin{array}{c}3.905 * * * \\
(1.435)\end{array}$ & & \\
\hline No. of local banks ( $>3 x$ size) & & & & $\begin{array}{c}-0.011^{*} \\
(0.006)\end{array}$ & \\
\hline No. of failed banks in state & & & & & $\begin{array}{c}0.002^{* * *} \\
(0.000)\end{array}$ \\
\hline Log(asset in \$000) & $\begin{array}{c}0.062 * * * \\
(0.012)\end{array}$ & $\begin{array}{c}0.051^{* * *} \\
(0.010)\end{array}$ & $\begin{array}{c}0.058 * * * \\
(0.012)\end{array}$ & $\begin{array}{c}0.060 * * * \\
(0.011)\end{array}$ & $\begin{array}{c}0.055 * * * \\
(0.010)\end{array}$ \\
\hline Observations & 456 & 456 & 456 & 456 & 456 \\
\hline Failed Year-Quarter FE & Yes & Yes & Yes & Yes & Yes \\
\hline Pseudo R-squared & 0.167 & 0.175 & 0.188 & 0.167 & 0.217 \\
\hline
\end{tabular}




\section{Table 4. Private Equity Bidding Activities}

This table presents the estimation results from a logit regression framework in the following form:

$$
\operatorname{Pr}(P E \text { Bidding }=1)=\Phi\left(\alpha+\beta \cdot X_{i}+\gamma \cdot \text { Control }_{i}+\theta_{t}+\varepsilon_{i}\right) .
$$

The analysis is performed on the cross-sectional sample of all failed banks in 2008-2015. Observation numbers are higher than in previous tables because additional failures in years 2008 and 2015 are added, in which a few PE bids were made on failed banks but did not win. The dependent variable is a dummy that takes value 1 if at least one PE bid on the failed bank and 0 otherwise (i.e., only bid on by banks). Panel A investigates characteristics of the failed banks themselves. Panel B investigates characteristics of the neighboring banks of the focal failed bank. All variables are defined in Table 2 and in Appendix 1. We control for the size of the bank measured using the logarithm of the total assets of the bank. Failed Year-Quarter fixed effects are included to account for the time-varying economic and regulatory environments that could affect the failed bank resolution process. Robust standard errors are displayed in parentheses. ${ }^{* *}, * *$, and $*$ indicate significance at the $1 \%, 5 \%$, and $10 \%$ levels, respectively.

Panel A: Characteristics of Failed Banks and PE Bidding

\begin{tabular}{|c|c|c|c|c|c|}
\hline & (1) & (2) & $\begin{array}{c}(3) \\
\text { I(PE Bidding })\end{array}$ & (4) & (5) \\
\hline \% Tier 1 risk-based capital ratio & $\begin{array}{c}-0.025^{* * *} \\
(0.006)\end{array}$ & & & & \\
\hline Core deposits to total deposits & & $\begin{array}{l}-0.162 \\
(0.158)\end{array}$ & & & \\
\hline Net interest margin (\%) & & & $\begin{array}{c}-0.056^{* * *} \\
(0.019)\end{array}$ & & \\
\hline C\&D loans to total loans & & & & $\begin{array}{c}0.152 \\
(0.389)\end{array}$ & \\
\hline OREO to total assets & & & & & $\begin{array}{l}0.656^{*} \\
(0.389)\end{array}$ \\
\hline Log(asset in \$000) & $\begin{array}{c}0.088^{* * *} \\
(0.015)\end{array}$ & $\begin{array}{c}0.080^{* * *} \\
(0.015)\end{array}$ & $\begin{array}{c}0.075 * * * \\
(0.015)\end{array}$ & $\begin{array}{c}0.080 * * * \\
(0.016)\end{array}$ & $\begin{array}{c}0.085 * * * \\
(0.015)\end{array}$ \\
\hline Observations & 487 & 487 & 487 & 487 & 487 \\
\hline Failed Year-Quarter FE & Yes & Yes & Yes & Yes & Yes \\
\hline Pseudo R-squared & 0.144 & 0.118 & 0.136 & 0.118 & 0.122 \\
\hline
\end{tabular}


Panel B: Financial Health of Neighbor Banks and the PE Bidders

(1)

(2)

(3)

(4)

(5)

I(PE Bidding)

Neighbor \% tier 1 risk-based capital ratio

$$
\begin{gathered}
-0.034^{* *} \\
(0.016)
\end{gathered}
$$

Neighbor noncurrent loans to total loans

$1.539 * * *$

$(0.461)$

Neighbor OREO to total assets

$$
6.718^{* * *}
$$

(2.043)

No. of local banks (>3xSize)

No. of failed banks in state

$\begin{array}{ccccc} & & & -0.005 & \\ & & & (0.008) & \\ & & & & 0.003 * * * \\ 0.097 * * * & 0.079 * * * & 0.091^{* * *} & 0.090^{* * *} & 0.090^{* * *} \\ (0.018) & (0.015) & (0.018) & (0.016) & (0.014)\end{array}$

Observations

\begin{tabular}{ccccc}
487 & 487 & 487 & 487 & 487 \\
Yes & Yes & Yes & Yes & Yes \\
0.137 & 0.151 & 0.158 & 0.129 & 0.204 \\
\hline
\end{tabular}

Failed Year-Quarter FE

Pseudo R-squared

0.137

0.151

0.204 


\section{Table 5. Balance Test of the Quasi-Random Bank Allocation to PE Investors and Banks}

This table provides the balance test for the quasi-random acquisition sample by comparing characteristics prior to bank failures. The sample consists of failed bank auctions in which (1) PE investors and banks both bid, (2) one is the winning bidder (acquirer) and one is the cover bid, and (3) the bidder value difference is smaller than five percent of total bank assets. The balance test compares the banks that were marginally won by a bank and those that were marginally won by a PE investor, and it reports the mean, the standard deviation, and the $t$-test of the two samples. Variables are defined in prior tables or used in tables to follow.

\begin{tabular}{|c|c|c|c|c|c|}
\hline \multirow[b]{3}{*}{ Failed bank characteristics } & \multicolumn{2}{|c|}{ PE-acquired } & \multicolumn{2}{|c|}{ Bank-acquired } & \multirow[b]{2}{*}{$t$-stat } \\
\hline & Mean & $\begin{array}{c}\text { Standard } \\
\text { Deviation }\end{array}$ & Mean & $\begin{array}{c}\text { Standard } \\
\text { Deviation }\end{array}$ & \\
\hline & & & & & \\
\hline Log(asset in \$000) & 12.758 & 0.829 & 13.073 & 1.464 & 0.921 \\
\hline \% Tier 1 risk-based capital ratio & 0.139 & 1.769 & 0.497 & 2.384 & 0.358 \\
\hline Core deposits to total deposits & 0.870 & 0.134 & 0.822 & 0.152 & -1.153 \\
\hline Net interest margin (\%) & 2.367 & 0.865 & 2.415 & 0.788 & 0.197 \\
\hline CRE loans to total loans & 0.444 & 0.148 & 0.482 & 0.168 & 0.834 \\
\hline$C \& D$ loans to total loans & 0.208 & 0.100 & 0.190 & 0.119 & -0.571 \\
\hline OREO to total assets & 0.077 & 0.068 & 0.051 & 0.071 & -1.198 \\
\hline \multicolumn{6}{|l|}{ Neighboring bank conditions } \\
\hline $\begin{array}{l}\text { Neighbor \% tier } 1 \text { risk-based } \\
\text { capital ratio }\end{array}$ & 7.735 & 1.475 & 7.188 & 2.445 & -0.940 \\
\hline $\begin{array}{l}\text { Neighbor noncurrent loans to } \\
\text { total loans }\end{array}$ & 0.059 & 0.049 & 0.045 & 0.039 & -1.411 \\
\hline Neighbor OREO to total assets & 0.015 & 0.015 & -0.037 & 0.215 & -1.200 \\
\hline \multicolumn{6}{|l|}{ Branch-level Conditions } \\
\hline $\begin{array}{l}\text { Branch closure rate (\%) (2005- } \\
\text { 2007) }\end{array}$ & 4.082 & 1.267 & 6.667 & 2.644 & 0.982 \\
\hline Branch deposits (\$000) & $51,777.11$ & $91,362.15$ & $57,660.35$ & $100,444.4$ & 0.513 \\
\hline \multicolumn{6}{|l|}{ County-level Condition } \\
\hline Log(SBA loan amount) & 15.463 & 1.881 & 15.900 & 2.075 & 1.304 \\
\hline Log(SBA loan number) & 2.672 & 1.541 & 3.136 & 1.925 & 1.640 \\
\hline SBA loan interest rate & 6.412 & 0.590 & 6.352 & 0.589 & -0.588 \\
\hline $\begin{array}{l}\text { Log(SBA loan average loan } \\
\text { size) }\end{array}$ & 12.791 & 0.841 & 12.764 & 0.839 & -0.187 \\
\hline Log(startup employment) & 8.197 & 1.755 & 8.337 & 2.235 & 0.430 \\
\hline Log(employment) & 8.565 & 1.834 & 8.654 & 2.310 & 0.264 \\
\hline$\Delta \log ($ total personal income) & 0.023 & 0.127 & 0.047 & 0.122 & 0.977 \\
\hline$\Delta \log ($ per capital income) & -0.032 & 0.052 & -0.034 & 0.034 & -0.256 \\
\hline
\end{tabular}




\section{Table 6. Branch Closing Post Failed Bank Acquisition-Branch-level Regression}

This table studies failed bank branch closings after being acquired by a PE investor or by another bank. The analysis uses the following specification at the branch $b$ level (located in region $z$ ), of bank $i$, that failed in year $t$ :

$$
\operatorname{Pr}(\text { Closing }=1)_{b, i, t, z}=\Phi\left(\alpha+\beta \cdot P E_{i}+\gamma \cdot \text { Control }_{i}+\theta_{t \times z}+\varepsilon_{i}\right) .
$$

The key explanatory variable is the dummy variable indicating whether the bank is acquired by a PE acquirer or by another bank. The dependent variable in columns (1) and (3) is a dummy variable indicating whether the branch closes within the three-year window post acquisition. Columns (2) and (4) use a dependent variable indicating whether the branch closes and simultaneously makes the bank exit the county. Control variables include those that have strong power in explaining PE investors' selection of acquisition-tier 1 risk-based capital ratio, core deposits to total deposits, C\&D loans to total loans, OREO to total assets, and total assets.

Fixed effects are included at the failed year by branch state level. Standard errors are double clustered at the state and failed year levels and are displayed in parentheses. ***, **, and * indicate significance at the 1\%, 5\%, and 10\% levels, respectively.

\begin{tabular}{|c|c|c|c|c|}
\hline & \multicolumn{2}{|c|}{ Quasi-Random Sample } & \multicolumn{2}{|c|}{ Full Sample } \\
\hline & (1) & $(2)$ & (3) & \\
\hline & Closing & $\begin{array}{l}\text { Close and Exit from } \\
\text { County }\end{array}$ & Closing & $\begin{array}{c}\text { Close and Exit from } \\
\text { County }\end{array}$ \\
\hline \multirow[t]{2}{*}{ I(PE Acquired) } & $-0.148^{* * *}$ & $-0.070 * *$ & $-0.072 * * *$ & $-0.027 * *$ \\
\hline & $(0.037)$ & $(0.029)$ & $(0.028)$ & $(0.013)$ \\
\hline \multirow[t]{2}{*}{ \% Tier 1 risk-based capital ratio } & -0.006 & -0.008 & 0.002 & 0.003 \\
\hline & $(0.004)$ & $(0.006)$ & $(0.003)$ & $(0.002)$ \\
\hline \multirow[t]{2}{*}{ Core deposits to total deposits } & $-0.929 * * *$ & $-0.657 * * *$ & $-0.537 * * *$ & $-0.224 * * *$ \\
\hline & $(0.233)$ & $(0.161)$ & $(0.107)$ & $(0.066)$ \\
\hline \multirow[t]{2}{*}{ C\&D loans to total loans } & $-0.282^{* *}$ & $-0.286 * * *$ & 0.039 & 0.027 \\
\hline & $(0.135)$ & $(0.107)$ & $(0.080)$ & $(0.053)$ \\
\hline \multirow{2}{*}{ OREO to total assets } & 0.645 & -0.137 & 0.158 & -0.210 \\
\hline & $(0.691)$ & $(0.358)$ & $(0.333)$ & $(0.194)$ \\
\hline \multirow[t]{2}{*}{ Log(asset in \$000) } & $-0.074 *$ & $-0.035 *$ & $-0.029 * * *$ & $-0.010 * *$ \\
\hline & $(0.031)$ & $(0.019)$ & $(0.005)$ & $(0.003)$ \\
\hline Observations & 617 & 617 & 4,476 & 4,476 \\
\hline R-squared & 0.345 & 0.234 & 0.236 & 0.143 \\
\hline State x Failed Year FE & Yes & Yes & Yes & Yes \\
\hline Mean of Dependent Var & 0.201 & 0.117 & 0.241 & 0.045 \\
\hline
\end{tabular}




\section{Table 7. Post-Acquisition Performance in Deposit Growth}

This table shows the deposit changes of bank- and PE-acquired failed bank branches post acquisition. The analysis is at the county-bank level, using the following specification,

$$
\Delta \text { Deposit }_{i, t, z}=\alpha+\beta \cdot P E_{i}+\gamma \cdot \text { Control }_{i}+\theta_{t \times z}+\varepsilon_{i} .
$$

The dependent variable is failed bank $i$ 's (in region $z$ ) one-year or three-year deposit change since $i$ 's year of failure $t$. For PE-acquired banks using shelf charters, this deposit change is for all branches in the local region; for bank-acquired banks or PE-acquired banks using inflatable charters or with multiple acquisitions, the deposits are calculated using both the failed bank branches and the branches originally owned by the acquirer bank in order to account for the measurement issues that may arise from reorganization. We only keep counties where the failed bank did not completely exit. The analysis incorporates a combination of state and failure year fixed effects. Standard errors are double clustered at the level of state and failed year, and they are displayed in parentheses. ${ }^{* * *}, * *$, and $*$ indicate significance at the $1 \%, 5 \%$, and $10 \%$ levels, respectively.

\begin{tabular}{|c|c|c|c|c|c|c|}
\hline & \multicolumn{2}{|c|}{ Quasi-Random Sample } & \multicolumn{2}{|c|}{ Full Sample } & \multicolumn{2}{|c|}{ Quasi-Random + No-overlap Sample } \\
\hline & $\begin{array}{c}(1) \\
1-Y r \Delta \text { Deposit }\end{array}$ & $\begin{array}{c}(2) \\
3-Y r \Delta \text { Deposit }\end{array}$ & $\begin{array}{c}(3) \\
1-Y r \Delta \text { Deposit }\end{array}$ & $\begin{array}{c}\text { (4) } \\
\text { 3-Yr } \Delta \text { Deposit }\end{array}$ & $\begin{array}{c}\text { (5) } \\
\text { 1-Yr } \Delta \text { Deposit }\end{array}$ & $\begin{array}{c}(6) \\
3-Y r \Delta \text { Deposit }\end{array}$ \\
\hline I(PE Acquired) & $\begin{array}{l}-0.018 \\
(0.141)\end{array}$ & $\begin{array}{c}0.356 * * * \\
(0.111)\end{array}$ & $\begin{array}{c}0.067 \\
(0.056)\end{array}$ & $\begin{array}{c}0.214 * * * \\
(0.037)\end{array}$ & $\begin{array}{l}-0.014 \\
(0.135)\end{array}$ & $\begin{array}{l}0.351^{* *} \\
(0.115)\end{array}$ \\
\hline Observations & 431 & 431 & 1,685 & 1,685 & 417 & 417 \\
\hline R-squared & 0.594 & 0.611 & 0.459 & 0.505 & 0.162 & 0.248 \\
\hline State $\mathrm{x}$ Failed Year FE & Yes & Yes & Yes & Yes & Yes & Yes \\
\hline Mean of Dependent Var & 0.0627 & -0.0288 & -0.0605 & -0.173 & 0.0408 & -0.0401 \\
\hline
\end{tabular}




\section{Table 8. Real Economic Outcomes: Small Business Lending}

This table studies regional economic activities after failed banks were acquired by a PE investor versus an incumbent bank. The analysis is at the county level, exploiting the quasi-random allocation of banks, and focuses on counties with only one type of acquirer. The analysis studies small business lending activities. The dependent variables are three-year growth of SBA lending activities in terms of quantity, total amount, interest rate, and average loan size. Panels A and B use the quasi-random sample and the full sample, respectively. The analysis incorporates a combination of state and failure year fixed effects. Standard errors are double clustered at the level of the state and failed year and are displayed in parentheses. ${ }^{* * *}, * *$, and $*$ indicate significance at the $1 \%, 5 \%$, and $10 \%$ levels, respectively.

Panel A: Small business lending activities_-Quasi-random sample

\begin{tabular}{lcccc}
\hline & $(1)$ & $(2)$ & $(3)$ & $(4)$ \\
& $\begin{array}{c}\Delta \text { SBA } \\
\text { Number }\end{array}$ & $\begin{array}{c}\Delta \text { SBA } \\
\text { Amount }\end{array}$ & $\begin{array}{c}\Delta \text { SBA Interest } \\
\text { Rate }\end{array}$ & $\begin{array}{c}\Delta \text { SBA Average } \\
\text { Loan Size }\end{array}$ \\
\hline & & & & \\
I(PE Acquired) & $0.320^{* *}$ & $0.154^{* *}$ & $-0.323^{*}$ & 0.165 \\
& $(0.112)$ & $(0.049)$ & $(0.147)$ & $(0.107)$ \\
Observations & & & & 276 \\
R-squared & 276 & 276 & 276 & 0.479 \\
State x Failed Year FE & 0.797 & 0.901 & 0.777 & Yes \\
\hline
\end{tabular}

Panel B: Small business lending activities-Full sample

\begin{tabular}{|c|c|c|c|c|}
\hline & $\begin{array}{c}(1) \\
\Delta \text { SBA } \\
\text { Number }\end{array}$ & $\begin{array}{c}(2) \\
\Delta \mathrm{SBA} \\
\text { Amount }\end{array}$ & $\begin{array}{c}\text { (3) } \\
\Delta \text { SBA Interest } \\
\text { Rate } \\
\end{array}$ & $\begin{array}{c}(4) \\
\Delta \text { SBA Average } \\
\text { Loan Size } \\
\end{array}$ \\
\hline I(PE Acquired) & $\begin{array}{l}0.125^{*} \\
(0.071)\end{array}$ & $\begin{array}{l}0.077^{*} \\
(0.042)\end{array}$ & $\begin{array}{c}-0.065^{*} \\
(0.035)\end{array}$ & $\begin{array}{l}-0.012 \\
(0.084)\end{array}$ \\
\hline Observations & 2,181 & 2,181 & 2,181 & 2,181 \\
\hline R-squared & 0.863 & 0.936 & 0.816 & 0.612 \\
\hline State $x$ Failed Year FE & Yes & Yes & Yes & Yes \\
\hline
\end{tabular}




\section{Table 9. Real Economic Outcomes: Regional Recovery}

This table studies regional economic activities after failed banks were acquired by a PE investor versus an incumbent bank. The analysis is at the county level, exploiting the quasi-random allocation of banks, and focuses on counties with only one type of acquirer. The analysis studies regional economic indicators, and the dependent variables are three-year growth in startup employment, total employment, total personal income, and per capita income. Panels A and B use the quasi-random sample and the full sample, respectively. The analysis incorporates a combination of state and failure year fixed effects. Standard errors are double clustered at the level of the state and failed year and are displayed in parentheses. ${ }^{* *}, * *$, and * indicate significance at the $1 \%, 5 \%$, and $10 \%$ levels, respectively.

Panel A: Regional economic recovery-Quasi-random sample

(2)

(3)

(4)

$\Delta$ Startup

Employment

$\Delta$ Employment

$\Delta$ Total Income

$\Delta$ Per Capita

Income

\begin{tabular}{lcccc} 
I(PE Acquired) & $0.042^{*}$ & $0.065^{* *}$ & $0.015^{* * *}$ & $0.007^{*}$ \\
& $(0.023)$ & $(0.029)$ & $(0.006)$ & $(0.004)$ \\
Observations & & & 276 & 276 \\
R-squared & 276 & 276 & 0.600 & 0.412 \\
State x Failed Year FE & 0.957 & 0.949 & Yes & Yes \\
\hline
\end{tabular}

Panel B: Regional economic recovery-Full sample

\begin{tabular}{|c|c|c|c|c|}
\hline & $\begin{array}{c}(1) \\
\Delta \text { Startup } \\
\text { Employment }\end{array}$ & $\begin{array}{c}(2) \\
\Delta \text { Employment }\end{array}$ & $\begin{array}{c}\text { (3) } \\
\Delta \text { Total Income }\end{array}$ & $\begin{array}{c}4) \\
\Delta \text { Per Capita } \\
\text { Income } \\
\end{array}$ \\
\hline I(PE Acquired) & $\begin{array}{c}0.026^{* *} \\
(0.012)\end{array}$ & $\begin{array}{c}0.039 * * \\
(0.015)\end{array}$ & $\begin{array}{l}0.011^{*} \\
(0.006)\end{array}$ & $\begin{array}{c}0.002 \\
(0.002)\end{array}$ \\
\hline Observations & 2,181 & 2,181 & 2,181 & 2,181 \\
\hline R-squared & 0.976 & 0.964 & 0.671 & 0.408 \\
\hline State $\mathrm{x}$ Failed Year FE & Yes & Yes & Yes & Yes \\
\hline
\end{tabular}




\section{Table 10. Loss Share Claims for Failed Banks}

This table studies loss share claims submitted by failed bank acquirers and examines the difference in whether the bank is acquired by a PE investor or by another bank. There were a total of 304 failed bank purchase agreements during the crisis that included loss share coverage. The analysis uses the following specification at the bank $i$, failure year-quarter $t$, and bank state $s$ level:

$$
\text { Loss Share }_{i, t, s}=\alpha+\beta \cdot P E_{i}+\gamma \cdot \text { Control }_{i}+\theta_{t \times s}+\varepsilon_{i} .
$$

The key explanatory variable is the dummy variable indicating whether the bank is acquired by a PE investor or by another bank. The dependent variable is the aggregate loss rate by the bank during the period of loss share coverage. We aggregate all the loss claims during the coverage period that could last for several years. This aggregated amount is then scaled by the total assets covered by the FDIC loss sharing agreement to give us a measure of total claimed losses comparable across different banks. Total loss rate is the total losses on the acquired portfolio as a ratio of covered assets. Incurred loss rate is the losses incurred by the acquirer as a ratio of covered assets after netting out any payments received from the FDIC according to the terms of the loss share agreement. Control variables include those that have strong power in explaining PE investors' selection of acquisition-tier 1 risk-based capital ratio, core deposits to total deposits, C\&D loans to total loans, and OREO to total assets. Fixed effects are included at the state-by-fail year level. Standard errors are clustered at the level of failed bank acquirers are displayed in parentheses. $* * *, * *$, and $*$ indicate significance at the $1 \%, 5 \%$, and $10 \%$ levels, respectively.

\begin{tabular}{|c|c|c|c|c|c|c|}
\hline & (1) & (2) & (3) & (4) & (5) & (6) \\
\hline & \multicolumn{6}{|c|}{ Total Loss Rate } \\
\hline & \multicolumn{3}{|c|}{ Total Loss Rate } & \multicolumn{3}{|c|}{ Incurred Loss Rate } \\
\hline I(PE Acquired) & $\begin{array}{c}-0.015 \\
(-0.544)\end{array}$ & $\begin{array}{c}-0.013 \\
(-0.406)\end{array}$ & $\begin{array}{c}0.044 \\
(0.690)\end{array}$ & $\begin{array}{c}0.007 \\
(0.648)\end{array}$ & $\begin{array}{c}0.003 \\
(0.207)\end{array}$ & $\begin{array}{c}-0.007 \\
(-0.263)\end{array}$ \\
\hline \% Tier 1 risk-based capital ratio & $\begin{array}{c}-0.005^{* *} \\
(-2.578)\end{array}$ & $\begin{array}{c}-0.007 * * \\
(-2.368)\end{array}$ & $\begin{array}{c}-0.024 \\
(-0.769)\end{array}$ & $\begin{array}{c}0.000 \\
(0.268)\end{array}$ & $\begin{array}{c}0.001 \\
(0.510)\end{array}$ & $\begin{array}{c}-0.002 \\
(-0.330)\end{array}$ \\
\hline Core deposits to total deposits & $\begin{array}{c}-0.028 \\
(-0.486)\end{array}$ & $\begin{array}{c}0.042 \\
(0.736)\end{array}$ & $\begin{array}{c}-0.049 \\
(-0.164)\end{array}$ & $\begin{array}{c}0.015 \\
(0.801)\end{array}$ & $\begin{array}{c}0.023 \\
(0.930)\end{array}$ & $\begin{array}{c}0.070 \\
(0.863)\end{array}$ \\
\hline C\&D loans to total loans & $\begin{array}{c}0.307^{* * *} \\
(5.688)\end{array}$ & $\begin{array}{c}0.334 * * * \\
(3.933)\end{array}$ & $\begin{array}{c}-0.300 \\
(-0.463)\end{array}$ & $\begin{array}{c}0.055^{* *} \\
(2.340)\end{array}$ & $\begin{array}{l}0.063^{*} \\
(1.921)\end{array}$ & $\begin{array}{c}-0.094 \\
(-0.681)\end{array}$ \\
\hline OREO to total assets & $\begin{array}{l}0.339 * \\
(1.694)\end{array}$ & $\begin{array}{c}0.560 * * * \\
(3.206)\end{array}$ & $\begin{array}{c}2.426 \\
(1.208)\end{array}$ & $\begin{array}{c}0.054 \\
(0.851)\end{array}$ & $\begin{array}{c}0.106 \\
(1.320)\end{array}$ & $\begin{array}{c}0.329 \\
(0.754)\end{array}$ \\
\hline Observations & 304 & 304 & 38 & 304 & 304 & 38 \\
\hline R-squared & 0.836 & 0.939 & 0.266 & 0.650 & 0.815 & 0.124 \\
\hline Quasi-random Sample & No & No & Yes & No & No & Yes \\
\hline State FE & Yes & No & No & Yes & No & No \\
\hline Failed Year FE & Yes & No & No & Yes & No & No \\
\hline State x Failed Year FE & No & Yes & No & No & Yes & No \\
\hline
\end{tabular}




\section{Table 11. Exit of PE-Acquired Banks}

This table presents the exit outcomes of PE-acquired failed banks as of 2020 Q1. We hand collect information on the exit of PE-acquired banks from FDIC structure reports on bank merger activity. We obtain details on IPO activity from S\&P Global Market Intelligence. The analysis is primarily performed at the acquiring bank level (consortium level) because different failed banks are lumped into one bank after being acquired by the same consortium under the same charter. We also report the bank-level counts that reflect the number of acquired failed banks in the acquiring consortia. The exit outcomes include still active, merger and acquisitions (acquired) or consolidated, IPO, and closed and liquidated. For acquired banks, we also code the acquirer identity. For the purpose of this table, Local bank buyer is identified here as a bank that has a branch network that overlaps with the acquired bank's branch network in at least one zip code. Non-local bank buyer is identified here as a bank that does not overlap with the acquired bank's branch network in at least one zip code.

\begin{tabular}{lcccc}
\hline \multirow{2}{*}{$\begin{array}{l}\text { Outcomes } \\
\text { PE-Acquired Failed Banks }\end{array}$} & \multicolumn{2}{c}{ Bank-Acquired Failed Banks } \\
Still active under acquirer ownership & 1 & 1 & 158 & 273 \\
\cline { 2 - 5 } Acquired or Merged & 15 & 52 & 54 & 95 \\
Local bank buyer & 9 & 30 & 24 & 47 \\
Non-local bank buyer & 6 & 22 & 30 & 48 \\
IPO & 2 & 4 & 11 & 24 \\
Closed and liquidated & 1 & 5 & 2 & 3 \\
\hline
\end{tabular}




\section{Table 12. Characteristics of Management in PE-acquired Banks}

This table presents the background information of the CEOs appointed by PE investors after acquiring failed banks. CEO background information is hand-collected from publicly available information on the internet, such as company bios, professional profiles, and featured articles. Prior experience in banking is an indicator variable for whether the new CEO appointed at the PE-acquired failed bank had a history of employment in commercial banking. Years of prior experience in banking is the number of years the individual was employed in commercial banking prior to joining the PE-acquired failed bank. Formerly at failed bank is an indicator variable for whether the CEO was at the failed bank prior to failure. (In most cases, the FDIC does not allow existing management to stay on at failed banks.) From PE firm is an indicator variable for whether the new CEO came directly from the PE firm. In all instances, CEOs came from the commercial banking industry. Local banking experience is an indicator variable for whether the CEOs had prior banking experience in the state where the PE acquisition was located. Community banking experience is an indicator variable for whether the CEO's prior experience was at a bank with a footprint within a single state (as opposed to regional or national footprints). Prior CEO of bank is an indicator variable for whether the CEO held a previous CEO position at a bank. While a little over half had prior CEO experience, all CEOs at PE-acquired banks had prior experience in upper banking management. Prior founding of bank is an indicator variable for whether the CEO had previously founded a bank. Almost a third of these CEOs had experience in starting up a new bank and later selling it. Prior experience in turnaround management, troubled debt, distressed assets is an indicator variable for whether the CEO had experience rehabilitating troubled institutions or products.

\begin{tabular}{lccccc}
\hline$N=19$ & Mean & $\begin{array}{c}\text { Standard } \\
\text { Deviation }\end{array}$ & Median & $\begin{array}{c}25^{\text {th }} \\
\text { percentile }\end{array}$ & $\begin{array}{c}75^{\text {th }} \\
\text { percentile }\end{array}$ \\
\hline Prior experience in banking & 1 & 0 & 1 & 1 & 1 \\
Years of prior experience in banking & 29.3 & 7.6 & 30 & 25 & 37 \\
Formerly at failed bank & 0 & 0 & 0 & 0 & 0 \\
From PE firm & 0 & 0 & 0 & 0 & 0 \\
Externally hired & 1 & 0 & 1 & 1 & 1 \\
Local banking experience & 0.63 & 0.51 & 1 & 0 & 1 \\
Community banking experience & 0.68 & 0.48 & 1 & 0 & 1 \\
Prior CEO of bank & 0.53 & 0.51 & 1 & 0 & 1 \\
Prior founding of bank & 0.32 & 0.48 & 0 & 0 & 1 \\
Prior experience in turnaround management, & 0.37 & 0.5 & 0 & 0 & 1 \\
troubled debt, distressed assets & & & & 0 \\
\hline
\end{tabular}




\section{Online Appendix for \\ Private Equity and Financial Stability: \\ Evidence from Failed Bank Resolution in the Crisis}

\author{
Emily Johnston-Ross \\ FDIC
}

\author{
Song Ma \\ Yale University
}

\author{
Manju Puri \\ Duke University, NBER, \\ and FDIC
}

Emily Johnston-Ross can be reached by phone: (202) 898-6841, email: emjohnston@fdic.gov. Song Ma can be reached by phone: (203) 436-4687, email: song.ma@yale.edu. Manju Puri can be reached by phone: (919) 660-7657, email: manju.puri@duke.edu. The analysis, conclusions, and opinions set forth here are those of the author(s) alone and do not necessarily reflect the views of the Federal Deposit Insurance Corporation. 


\section{Online Appendix 1. Sample of Failed Bank Acquisitions and PE Participation}

In this appendix, we provide details on the sample construction of failed banks in our main analysis, which focuses on 456 failed bank acquisitions. None of the data processing steps described below change the results of the paper in any meaningful way, either qualitatively or quantitatively.

From 2009-2014 (the main dates of our sample, because these are the years in which PE investors acquired failed banks), the cumulative number of failed bank observations is 483 . This

includes 394 bank failures acquired by banks, ${ }^{1} 62$ bank failures acquired by PE investors, ${ }^{2} 25$ failures that received no winning bid and were thus liquidated by the FDIC, and 2 banks that were temporarily run by the FDIC as bridge banks. The 25 liquidations and 2 bridge banks are excluded from our analysis, leaving $394+62=456$ failed bank acquisitions for our main analysis.

The amount of assets at the failed banks in Figure 1, Panel B shows total assets held at failed banks in the quarter before failure. The sample includes assets at banks that were acquired, liquidated, or temporarily run as a conservatorship or bridge bank. These numbers differ from the total assets acquired, depicted in Figure 3, Panel B. Figure 3 only includes assets from banks that were acquired, so it excludes any assets from banks that were liquidated and two bankers' banks that failed and were temporarily run as bridge banks by the FDIC. In addition, acquirers rarely purchase 100 percent of the assets at the failed bank, so the FDIC retains a large portion overall. Any assets retained by the FDIC in the resolution process are excluded from the measure of assets acquired. This is why the amount of assets at failure and the amount of assets acquired are different between Figure 1, Panel B, and Figure 3, Panel B, in the paper, capturing details of bank failures vs. acquisitions.

\footnotetext{
${ }^{1}$ One bank that failed in 2010 was split between two different acquirers - these are counted as separate observations in our analysis.

${ }^{2}$ One bank failed in 2008 but was run by the FDIC as a conservatorship before being acquired in 2009 by a PE entity.
} 
Online Appendix 2. Additional Results

A.3 


\section{Table A1. Bank Failures and PE Participation in Resolutions}

This table shows the number and size of failed bank acquisitions by year. Column (1) is the year in which the acquisition occurred. Column (2) is the total number of failed bank acquisitions in a given year. Column (3) is the total amount of failed bank assets in millions acquired in a given year from internal resolution data at the FDIC. Column (4) is the number of failed banks acquired by PE in a given year. Column (5) is the percentage of failed bank acquisitions by PE in a given year relative to the total failed bank acquisitions that year. Column (6) is the total assets in millions passed to the acquiring banks in a given year from internal FDIC resolutions data. Column (7) is the percentage of assets acquired by PE in a given year relative to total assets acquired in that year. Column (8) is the number of failed banks acquired by banks in a given year. Column (9) is the percentage of failed bank acquisitions by banks in a given year relative to the total failed bank acquisitions that year. Column (10) is the total assets passed to the bank acquirers in a given year from internal FDIC resolutions data. Column (11) is the percentage of assets acquired by banks in a given year relative to total assets acquired in that year.

\begin{tabular}{|c|c|c|c|c|c|c|c|c|c|c|}
\hline \multirow[t]{2}{*}{ Year } & \multicolumn{2}{|c|}{ Total failed bank acquisitions } & \multicolumn{4}{|c|}{ Failed banks acquired by PE } & \multicolumn{4}{|c|}{ Failed banks acquired by other banks } \\
\hline & Number & $\begin{array}{l}\text { Total assets } \\
\text { (\$Million) }\end{array}$ & Number & $\%$ & $\begin{array}{l}\text { Total assets } \\
\text { (\$Million) }\end{array}$ & $\%$ & Number & $\%$ & $\begin{array}{l}\text { Total assets } \\
\text { (\$Million) }\end{array}$ & $\%$ \\
\hline 2009 & 129 & 151,605 & 11 & $8.53 \%$ & 38,181 & $25.18 \%$ & 118 & $91.47 \%$ & 113,423 & $74.82 \%$ \\
\hline 2010 & 149 & 79,620 & 22 & $14.67 \%$ & 15,847 & $19.90 \%$ & 127 & $85.33 \%$ & 63,774 & $80.10 \%$ \\
\hline 2011 & 90 & 31,888 & 20 & $22.22 \%$ & 10,240 & $32.11 \%$ & 70 & $77.78 \%$ & 21,648 & $67.89 \%$ \\
\hline 2012 & 47 & 8,723 & 5 & $10.64 \%$ & 1,149 & $13.17 \%$ & 42 & $89.36 \%$ & 7,574 & $86.83 \%$ \\
\hline 2013 & 23 & 4,794 & 2 & $8.70 \%$ & 363 & $7.57 \%$ & 21 & $91.30 \%$ & 4,431 & $93.43 \%$ \\
\hline 2014 & 18 & 2,173 & 2 & $11.11 \%$ & 210 & $9.68 \%$ & 16 & $88.89 \%$ & 1,963 & $90.32 \%$ \\
\hline Overall & 456 & 278,803 & 62 & $13 \%$ & 65,990 & $24 \%$ & 394 & $87 \%$ & 212,813 & $76 \%$ \\
\hline
\end{tabular}


Table A2. Summary Statistics of the Failed Banks

This table presents summary statistics for failed bank acquisitions by PE and other banks between 2009 and 2014. Asset size is the amount of assets at the failed bank in millions. \% Tier 1 risk-based capital is the Tier 1 risk-based capital divided by adjusted average assets, as a percentage. Liquidity ratio is the sum of cash, fed funds sold, and securities (excluding mortgage-backed securities) divided by total assets. Core deposits to total deposits is total domestic deposits minus time deposits of more than $\$ 250,000$ and brokered deposits of $\$ 250,000$ or less divided by total deposits. CRE loans to total loans is non-farm, non-residential properties secured by real estate and multifamily ( 5 or more) residential properties secured by real estate divided by total loans. C\&D loans to total loans is construction and land development loans secured by real estate divided by total loans. C\&I loans to total loans is commercial and industrial loans divided by total loans. Consumer loans to total loans is loans to individuals for household, family, and other personal expenditures divided by total loans. Noncurrent loans to total loans is the ratio of noncurrent loans to total loans. OREO to total assets is the ratio of other real estate owned to total assets. Loss-sharing agreement is an indicator variable that equals 1 if the transaction included an agreement with the FDIC to share in a portion of the losses on covered assets and 0 if no loss-sharing agreement was included. Neighboring bank variables are constructed as the mean of banks that share at least one branch zip code with the focal bank.

Failed bank characteristics

\begin{tabular}{cccc}
\multicolumn{4}{c}{ PE Acquisitions } \\
$\mathrm{N}$ & Mean & Standard & \multirow{2}{*}{ Median } \\
\hline
\end{tabular}

\begin{tabular}{|c|c|c|c|}
\hline \multicolumn{4}{|c|}{ Bank Acquisitions } \\
\hline $\mathrm{N}$ & Mean & $\begin{array}{c}\text { Standard } \\
\text { Deviation }\end{array}$ & Median \\
\hline
\end{tabular}

T-test

t-stat $\quad p$-val

Asset size (\$ millions)

$\%$ Tier 1 risk-based capital ratio

Liquidity ratio

Core deposits to total deposits

Net interest margin (\%)

CRE loans to total loans

C\&D loans to total loans

C\&I loans to total loans

Consumer loans to total loans

Residential loans to total loans

Noncurrent loans to total loans

OREO to total assets

Loss-sharing agreement

\section{2}

\section{2}

62

62

62

62

62

62

62

62

62

62

62

Neighboring bank conditions

Neighbor \% tier 1 risk-based capital ratio

Neighbor noncurrent loans to total loans

Neighbor OREO to total assets

No. of Local Banks (>3xSize)

No. of Failed Banks in State

\begin{tabular}{|c|c|c|c|c|c|c|c|c|}
\hline 1,354 & 4,216 & 341 & 394 & 628 & 1,890 & 193 & $-2.267 * *$ & 0.024 \\
\hline 0.165 & 2.418 & 0.615 & 394 & 1.045 & 2.722 & 1.190 & $2.402 * *$ & 0.017 \\
\hline 0.168 & 0.085 & 0.156 & 394 & 0.168 & 0.081 & 0.156 & 0.030 & 0.976 \\
\hline 0.824 & 0.148 & 0.889 & 394 & 0.839 & 0.144 & 0.874 & 0.753 & 0.452 \\
\hline 2.019 & 1.320 & 2.115 & 394 & 2.634 & 1.217 & 2.625 & $3.655^{* * *}$ & 0.001 \\
\hline 0.400 & 0.165 & 0.394 & 394 & 0.385 & 0.171 & 0.378 & -0.649 & 0.516 \\
\hline 0.227 & 0.149 & 0.199 & 394 & 0.179 & 0.135 & 0.152 & $-2.571^{* *}$ & 0.011 \\
\hline 0.083 & 0.080 & 0.065 & 394 & 0.111 & 0.090 & 0.085 & $2.284^{* *}$ & 0.023 \\
\hline 0.014 & 0.013 & 0.010 & 394 & 0.024 & 0.042 & 0.012 & $1.842 *$ & 0.066 \\
\hline 0.253 & 0.184 & 0.209 & 394 & 0.260 & 0.184 & 0.237 & 0.303 & 0.762 \\
\hline 0.183 & 0.088 & 0.162 & 394 & 0.161 & 0.096 & 0.143 & $-1.716^{*}$ & 0.087 \\
\hline 0.065 & 0.057 & 0.051 & 394 & 0.050 & 0.047 & 0.037 & $-2.386 * *$ & 0.017 \\
\hline 0.839 & 0.371 & 1 & 394 & 0.632 & 0.483 & 1 & $-3.224 * * *$ & 0.001 \\
\hline 7.692 & 1.274 & 7.713 & 394 & 7.972 & 1.345 & 7.956 & -1.479 & 0.140 \\
\hline 0.048 & 0.041 & 0.038 & 394 & 0.034 & 0.033 & 0.022 & $2.870^{* * *}$ & 0.004 \\
\hline 0.012 & 0.013 & 0.006 & 394 & 0.006 & 0.009 & 0.003 & $4.106^{* * *}$ & 0.000 \\
\hline 2.949 & 1.682 & 2.000 & 394 & 3.337 & 2.178 & 3.000 & -1.300 & 0.194 \\
\hline 52.9 & 29.4 & 69 & 394 & 35.0 & 27.9 & 21 & $17.9 * * *$ & 0.000 \\
\hline
\end{tabular}




\section{Table A3. Robustness: Comparing PE-Acquired and Bank-Acquired Failed Banks}

This table presents the estimation results from a logit regression framework in the following form:

$$
\operatorname{Pr}(P E=1)=\Phi\left(\alpha+\beta \cdot X_{i}+\gamma \cdot \text { Control }_{i}+\theta_{t}+\varepsilon_{i}\right) .
$$

The analysis is performed on the cross-sectional sample of all failed banks that eventually got acquired by a bank or a private equity investor. The dependent variable is a dummy that takes value 1 if the failed bank was eventually acquired by a PE investor and 0 otherwise (i.e., acquired by a bank). This table differs from Table 3 of the paper by using alternative definitions of PE acquisitions. We required PE holding to be above $75 \%$ or $66 \%$ respectively.

$(1)$

(2)

(3)

(4)

(5)
\% Tier 1 risk-based capital ratio $\quad-0.011^{* *}$

Core deposits to total deposits

Net interest margin (\%)

C\&D loans to total loans

OREO to total assets

Log(asset in \$000)

Observations

Failed Year-Quarter FE

Pseudo R-squared
$-0.268 * *$

(-2.073)

$-0.075 * * *$

(-4.657)

$0.347^{* *}$

(2.480)

$0.728^{* * *}$

(2.654)

$0.052^{* * *} \quad 0.048^{* * *} \quad 0.043^{* * *} \quad 0.043^{* * *} \quad 0.054^{* * *}$

$(4.099) \quad(3.931) \quad(3.587) \quad(2.807) \quad(4.260)$

\begin{tabular}{ccccc}
408 & 408 & 408 & 408 & 408 \\
Yes & Yes & Yes & Yes & Yes \\
0.131 & 0.132 & 0.204 & 0.148 & 0.138 \\
\hline
\end{tabular}




\begin{tabular}{|c|c|c|c|c|c|}
\hline & $(1)$ & $(2)$ & (3) & (4) & (5) \\
\hline & \multicolumn{5}{|c|}{$\operatorname{Pr}(\mathrm{PE}$ Acquired); PE defined as PE Ownership > 66\% } \\
\hline \% Tier 1 risk-based capital ratio & $\begin{array}{c}-0.012 * * \\
(-2.300)\end{array}$ & & & & \\
\hline Core deposits to total deposits & & $\begin{array}{l}-0.248^{*} \\
(-1.858)\end{array}$ & & & \\
\hline Net interest margin (\%) & & & $\begin{array}{c}-0.082 * * * \\
(-4.849)\end{array}$ & & \\
\hline C\&D loans to total loans & & & & $\begin{array}{c}0.365^{* *} \\
(2.512)\end{array}$ & \\
\hline OREO to total assets & & & & & $\begin{array}{c}0.866^{* * *} \\
(3.262)\end{array}$ \\
\hline Log(asset in $\$ 000$ ) & $\begin{array}{c}0.060^{* * *} \\
(4.554)\end{array}$ & $\begin{array}{c}0.056^{* * *} \\
(4.391)\end{array}$ & $\begin{array}{c}0.050^{* * *} \\
(4.090)\end{array}$ & $\begin{array}{c}0.050 * * * \\
(3.271)\end{array}$ & $\begin{array}{c}0.061^{* * *} \\
(4.770)\end{array}$ \\
\hline Observations & 428 & 428 & 428 & 428 & 428 \\
\hline Failed Year-Quarter FE & Yes & Yes & Yes & Yes & Yes \\
\hline Pseudo R-squared & 0.156 & 0.152 & 0.229 & 0.171 & 0.169 \\
\hline
\end{tabular}




\section{Table A4. Robustness: Comparing PE-Acquired and Bank-Acquired Failed Banks}

This table presents the estimation results from a logit regression framework in the following form:

$$
\operatorname{Pr}(P E=1)=\Phi\left(\alpha+\beta \cdot X_{i}+\gamma \cdot \text { Control }_{i}+\theta_{t}+\varepsilon_{i}\right) .
$$

The analysis is performed on the cross-sectional sample of all failed banks that eventually got acquired by a bank or a private equity investor. The dependent variable is a dummy that takes value 1 if the failed bank was eventually acquired by a PE investor and 0 otherwise (i.e., acquired by a bank). This table differs from Table 3 of the paper by simultaneously incorporating bank characteristics of the failed banks and their neighboring banks, as defined in the paper.

(1)

(2)

(3)

(4)

(5) I(PE Acquired)

\% Tier 1 risk-based capital ratio $-0.017^{* * *}$

(0.005)

Neighbor \% tier 1 risk-based capital ratio $-0.018^{*}$

Core deposits to total deposits (0.011)

Core deposits to total deposits

Neighbor core deposits to total deposits

$(0.254)$

-0.401 *

$(0.217)$

Net interest margin (\%)

$-0.073^{* * *}$

$(0.021)$

Neighbor net interest margin (\%)

$-0.012$

$(0.041)$

C\&D loans to total loans

$0.309 * * *$

$(0.101)$

$0.324 * *$

(0.147)

OREO to total assets

$0.492 * *$

(0.234)

Neighbor OREO to total assets

Log(asset in \$000)

$0.064 * * *$

0.029*

$0.027 * *$

(1.444)

(0.012)

(0.018)

(0.011)

$0.025 * *$

$0.060 * * *$

Observations

$\begin{array}{ccccc}456 & 456 & 456 & 456 & 456 \\ \text { Yes } & \text { Yes } & \text { Yes } & \text { Yes } & \text { Yes } \\ 0.198 & 0.118 & 0.141 & 0.0951 & 0.196\end{array}$

Failed Year-Quarter FE

Pseudo R-squared

(0.010)

(0.012)

Pseudo R-squared

